\title{
The Tetrapod Fossil Record from the Uppermost Maastrichtian of the Ibero-Armorican Island: An Integrative Review Based on the Outcrops of the Western Tremp Syncline (Aragón, Huesca Province, NE Spain)
}

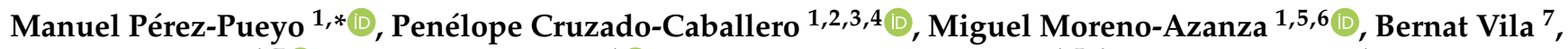 \\ Diego Castanera ${ }^{1,7}$, José Manuel Gasca ${ }^{1}$ (D), Eduardo Puértolas-Pascual 1,5,6, Beatriz Bádenas ${ }^{1}$ \\ and José Ignacio Canudo ${ }^{1}$ (D)
}

check for

updates

Citation: Pérez-Pueyo, M.; Cruzado-Caballero, P.; Moreno-Azanza, M.; Vila, B.; Castanera, D.; Gasca, J.M.; Puértolas-Pascual, E.; Bádenas, B.; Canudo, J.I. The Tetrapod Fossil Record from the Uppermost Maastrichtian of the Ibero-Armorican Island: An Integrative Review Based on the Outcrops of the Western Tremp Syncline (Aragón, Huesca Province, NE Spain). Geosciences 2021, 11, 162. https://doi.org/10.3390/ geosciences 11040162

Academic Editors:

Angelos G. Maravelis and Jesus Martinez-Frias

Received: 25 February 2021

Accepted: 26 March 2021

Published: 2 April 2021

Publisher's Note: MDPI stays neutral with regard to jurisdictional claims in published maps and institutional affiliations.

Copyright: (c) 2021 by the authors. Licensee MDPI, Basel, Switzerland. This article is an open access article distributed under the terms and conditions of the Creative Commons Attribution (CC BY) license (https:// creativecommons.org/licenses/by/ $4.0 /)$.
1 Grupo Aragosaurus-IUCA, Facultad de Ciencias, Universidad de Zaragoza, C/Pedro Cerbuna, 12, 50009 Zaragoza, Aragón, Spain; pcruzado@ull.edu.es (P.C.-C.); mmazanza@fct.unl.pt (M.M.-A.); diego.castanera@icp.cat (D.C.); jmgaska@hotmail.com (J.M.G.); puertolas@fct.unl.pt (E.P.-P.); bbadenas@unizar.es (B.B.); jicanudo@unizar.es (J.I.C.)

2 Área de Paleontología, Departamento de Biología Animal, Edafología y Geología, Universidad de La Laguna, 38200 San Cristóbal de La Laguna, Santa Cruz de Tenerife, Spain

3 Instituto de Investigación en Paleobiología y Geología (IIPG), Universidad Nacional de Río Negro, 8500 Río Negro, Argentina

4 IIPG, UNRN, Consejo Nacional de Investigaciones Científicas y Técnicas (CONICET), 2300 Buenos Aires, Argentina

5 GEOBIOTEC, Department of Earth Sciences, NOVA School of Science and Technology, Campus de Caparica, 2829-516 Caparica, Portugal

6 Espaço Nova Paleo, Museu de Lourinhã, Rua João Luis de Moura 95, 2530-158 Lourinhã, Portugal

7 Institut Català de Paleontologia Miquel Crusafont, Universitat Autònoma de Barcelona, c/ Escola Industrial 23, 08201 Sabadell, Barcelona, Spain; bernat.vila@icp.cat

* Correspondence: manuppueyo@unizar.es

Abstract: The South-Pyrenean Basin (northeastern Spain) has yielded a rich and diverse record of Upper Cretaceous (uppermost Campanian-uppermost Maastrichtian) vertebrate fossils, including the remains of some of the last European dinosaurs prior to the Cretaceous-Paleogene (K-Pg) extinction event. In this work, we update and characterize the vertebrate fossil record of the Arén Sandstone and Tremp formations in the Western Tremp Syncline, which is located in the Aragonese area of the Southern Pyrenees. The transitional and continental successions of these sedimentary units are dated to the late Maastrichtian, and exploration of their outcrops has led to the discovery of numerous fossil remains (bones, eggshells, and tracks) of dinosaurs, including hadrosauroids, sauropods, and theropods, along with other tetrapods such as crocodylomorphs, testudines, pterosaurs, squamates, and amphibians. In particular, this fossil record contains some of the youngest lambeosaurine hadrosaurids (Arenysaurus and Blasisaurus) and Mesozoic crocodylomorphs (Arenysuchus and Agaresuchus subjuniperus) in Europe, complementing the lower Maastrichtian fossil sites of the Eastern Tremp Syncline. In addition, faunal comparison with the fossil record of Hateg island reveals the great change in the dinosaur assemblages resulting from the arrival of lambeosaurine hadrosaurids on the Ibero-Armorican island, whereas those on Haţeg remained stable. In the light of its paleontological richness, its stratigraphic continuity, and its calibration within the last few hundred thousand years of the Cretaceous, the Western Tremp Syncline is one of the best places in Europe to study the latest vertebrate assemblages of the European Archipelago before the end-Cretaceous mass extinction.

Keywords: late Maastrichtian; Western Tremp Syncline; Southern Pyrenees; tetrapods; IberoArmorican island 


\section{Introduction}

The Cretaceous-Paleogene (K-Pg) extinction event is undoubtedly one of the most debated topics in the evolutionary history of life on the planet. Ever since a catastrophic meteorite impact at the end of the Maastrichtian was proposed as the major cause of the extinction [1], scientific debate on this event has been of ongoing significance. At the end of the Cretaceous, a set of destabilizing events occurred on Earth, including a marine regression [2], climate changes [3,4], the volcanic activity of the Deccan Volcanic Province (India) with the emission of a huge amount of gases and volcanic material into the atmosphere [5-8], and the impact of an asteroid in Chicxulub (Mexico) $66 \mathrm{Ma}$ ago [1,9-12]. Although all these causes seem to have contributed to the extinction to a certain degree, the meteorite impact hypothesis shows the most solid arguments for having been the major disturbing mechanism [12-16].

Whatever the cause, the K-Pg extinction eradicated nearly $70 \%$ of the living species on Earth $[17,18]$. Among vertebrates, this event led to the disappearance of several groups, including non-avian dinosaurs, enantiornithine birds, pterosaurs, mosasaurs, plesiosaurs, and several lineages of crocodylomorphs, among others [19-23]. However, the mechanism by which they became extinct and how fast they did so remain difficult questions for researchers, as is the issue of how determinant the Chicxulub impact was on the stability of the ecosystems. Except for the Hell Creek Formation in North America, whose vertebrate faunas are well known [22,24,25] and their chronostratigraphic framework is well constrained [26-29], the main difficulty in assessing the end-Cretaceous extinction is the lack of well-studied sedimentary formations with vertebrate remains encompassing the K-Pg boundary. In Europe, a great effort has been made in recent decades to characterize the terrestrial uppermost Cretaceous-Paleocene formations, especially in Spain, France, and Romania (e.g., [30-33]). The best-known deposits are those from the so-called Ibero-Armorican island, which encompassed the current south of France and the northeast of Spain (Languedoc, Provence, and the Pyrenees), and other outcrops in the east, northwest, and center of Spain and part of Portugal. Of these regions, the South-Pyrenean Basin is the best-known area. Since the end of the 20th century, several research teams have worked on the uppermost Campanian-Danian outcrops in this area, improving our knowledge of the biodiversity of fossil vertebrates, the environments they inhabited, and the chronostratigraphic framework $[31,33,34]$.

The main objectives of this paper are to review the paleontological and stratigraphical data of the western sector of the Tremp Syncline (Figure 1a), which are characterized by the thickest and most continuous upper Maastrichtian succession in the South-Pyrenean Basin, and to integrate these data within the Ibero-Armorican Maastrichtian record as a whole. Work in this area has led to the discovery of more than 50 vertebrate fossil sites and the erection of four taxa. Such a record enables us to characterize the extinction patterns of the tetrapods of the Ibero-Armorican island, especially in the last few hundred thousand years of the Maastrichtian, and to ascertain how the ecological communities were affected by the asteroid impact and its consequences.

\section{The Geological and Stratigraphic Framework of the Western Tremp Syncline (Aragonese Outcrops of the Tremp Fm)}

The Western Tremp Syncline is the westernmost edge of the Tremp Syncline or TrempGraus Basin, the largest of the sub-basins into which the Southern Pyrenees was compartmentalized by several structural hights [35]. The Pyrenees is a mountain range located in the northeast of the Iberian Peninsula between Spain and France (Figure 1a). It is structured as an asymmetric range, a NW-SE oriented belt of folds and thrusts, which was formed as a product of the collision between the European plate and the Iberian microplate. This collision took place during the Alpine orogeny between the Late Cretaceous and the Miocene [36-39]. The thrust sheets of the orogen controlled the development of a series of compartmentalized foreland basins, parallel to the axis of the orogen, which were active in different tectonic stages. The South-Pyrenean Basin was active between the Late 
Cretaceous and the Oligocene and was connected with the Atlantic Ocean until the Late Eocene [40]. For this reason, its sedimentary record consists mainly of marine sediments, although at the end of the Late Cretaceous, as a consequence of the global sea level fall [2], the basin was progressively filled with westward-prograding turbiditic and deltaic sediments (Santonian-Maastrichtian) [41] and transitional and continental deposits (lower to upper Maastrichtian) [35,42]. Continental sedimentation lasted up to the Paleocene.

The Tremp Syncline or Tremp-Graus Basin is limited in the north by the Bóixols thrust sheet and in the south by the Montsec thrust sheet (Figure 1a). In the Tremp Syncline, the uppermost Cretaceous-lowermost Paleocene transitional and continental deposits consist of two closely related stratigraphic units, the Arén and Tremp formations (see lithostratigraphy by [43]; Figure 1b). The uppermost Cretaceous outcrops of the Western Tremp Syncline (sensu [33]) studied here comprise those located between the rivers Noguera Ribagorzana and Ésera. Thus, they constitute the part of the Tremp Syncline situated within the region of Aragón (Huesca province) (Figure 1a).

The Arén Sandstone Fm [44] is a middle Campanian-Maastrichtian transitional unit constituted by a thick succession of calcarenites with large-scale cross-bedding, which is composed mainly of quartz grains and bioclasts [45]. It represents deposition in different transitional sedimentary environments including delta [46], barrier-island [45,47], and beach deposits $[48,49]$. These deposits pass laterally and vertically to the Tremp Fm, since their boundary is not isochronous.

The Tremp Fm [44], traditionally known as the 'Garumnian Facies' [50], is a coastal to continental heterogeneous and diachronous lithostratigraphic unit that ranges between the Maastrichtian and the Paleocene. It can be subdivided into four minor lithostratigraphic units, which have received different names in the successive stratigraphic subdivisions proposed (Figure 1b) [42-44,51,52]. The scheme used here is that of Rosell et al. (2001) [43], who divided the Tremp Fm into four informal units recognizable throughout the SouthPyrenean Basin.

The lowermost unit is the so-called "Grey Garumnian", which is characterized by a succession of grey marls and mudstones, with intercalations of sandstones, limestones, and coal beds and a rich fossil content of brackish and continental invertebrate faunas. It is interpreted as transitional deposits, including lagoon, tidal mud flats, swamp and marsh sub-environments [42,43,47,51,53-56]. The overlying unit is the 'Lower Red Garumnian', which is composed of reddish, brown ochre, and multi-colored mudstones, with local paleosoils and intercalated lenticular sandstone packages, sometimes with channelized bases and point-bar deposits. There are also carbonate intercalations of lacustrine origin. The 'Lower Red Garumnian' has been interpreted either as fluvial and alluvial deposits $[43,51,55]$ or as deltaic-plain and perilagoonal deposits in the Western Tremp Syncline [54]. The fluvial deposits show features indicative of a marked tidal influence in the basin [54,56-58]. The 'Grey Garumnian' and 'Lower Red Garumnian' successions studied here are of Maastrichtian age, having been dated by means of the biostratigraphy of planktonic foraminifera and charophytes [56,59-61] and by magnetostratigraphy [31,62-64]. Nevertheless, due to sedimentary evolution and syntectonic activity during the Maastrichtian, the age of these units varies throughout the basin, being younger westwards $[41,63]$. Thus, the lower Maastrichtian is only represented in the eastern part of the basin, whereas the upper Maastrichtian is much better recorded in its western part. This distribution implies the presence in the eastern part of a sedimentary hiatus within the 'Lower Red Garumnian', between chron C31r and chron C29r [63]. 
a)

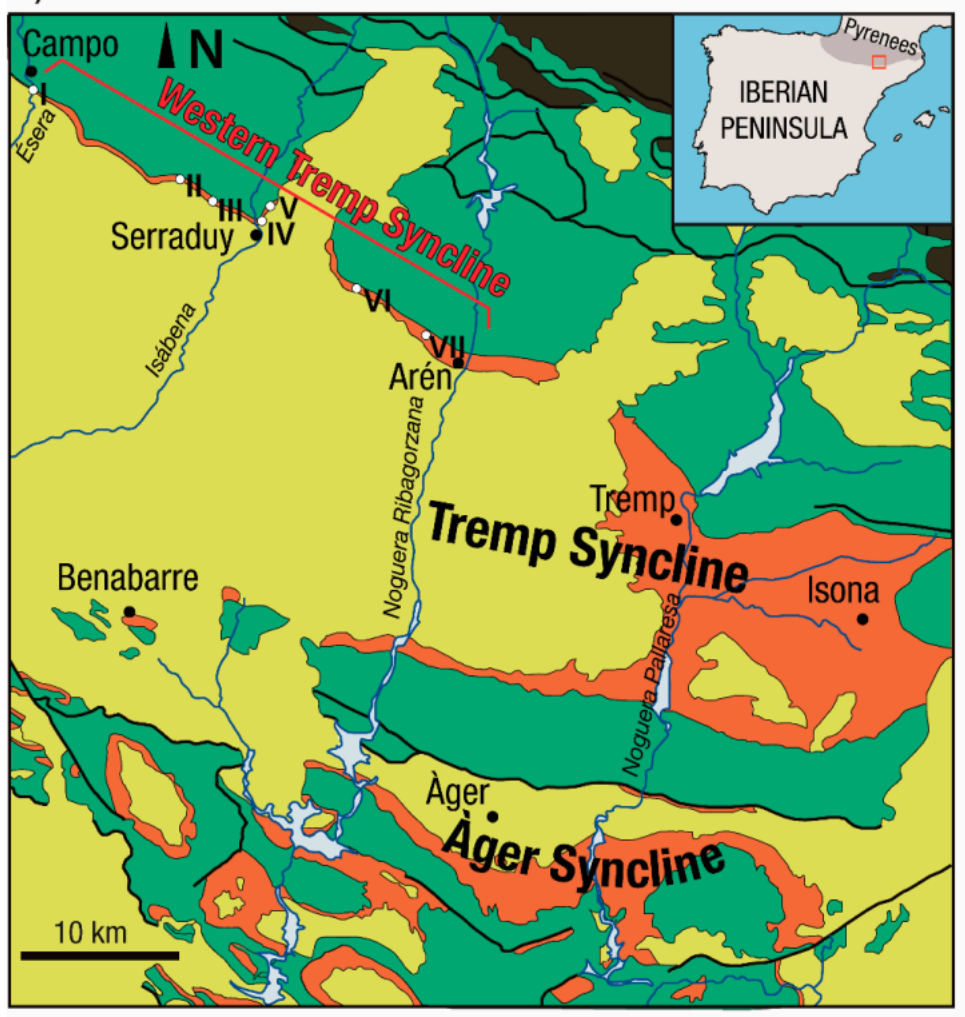

$\square$ Cenozoic units Tremp Fm (Maastrichtian-Danian)

Mesozoic units (including Arén Fm)

Palaeozoic basement

Main thrusts

Reference sections

I. Campo

II. Larra

III. Rin

IV. Serraduy

V. Beranuy

VI. Iscles

VII. Arén/Areny

b)

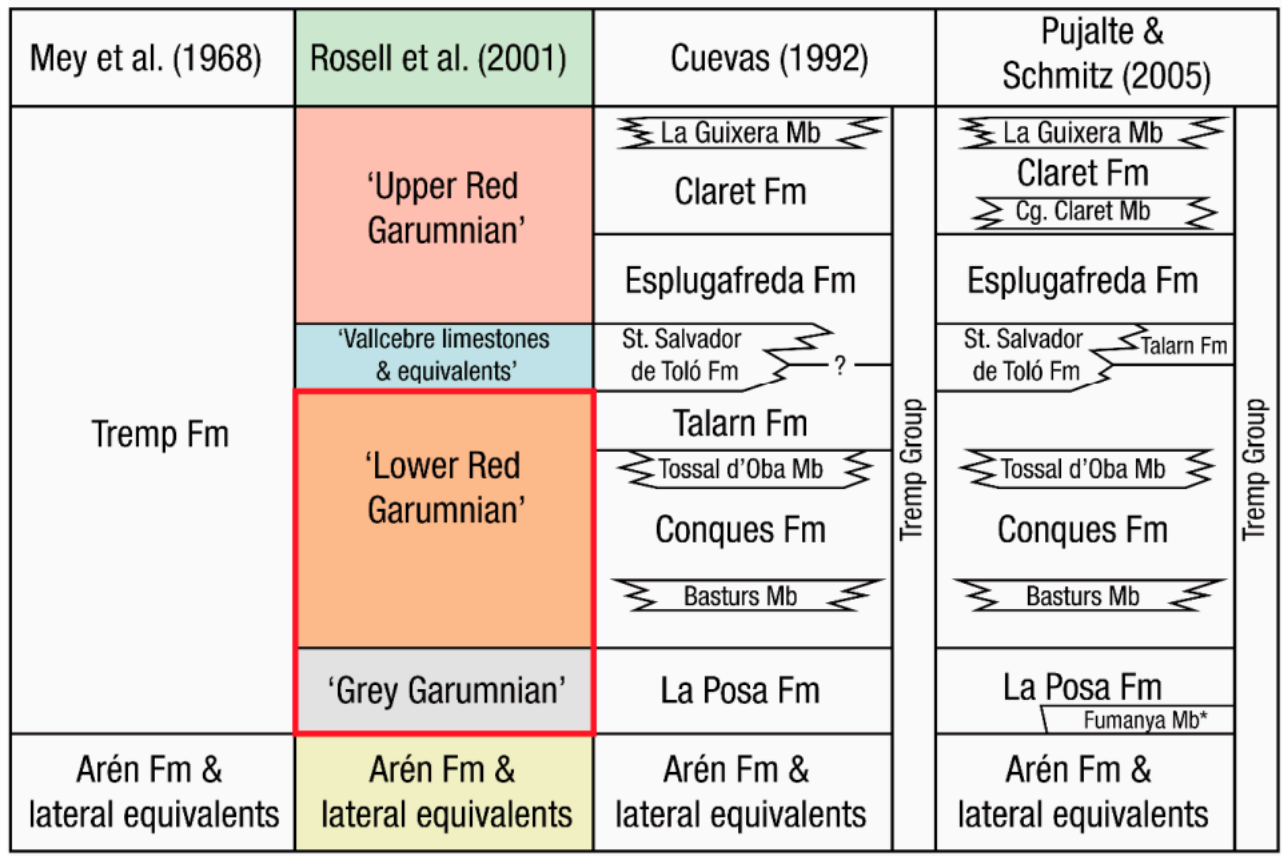

* defined by $0 \mathrm{~ms}$ et al., 2016

Figure 1. Geological and stratigraphic setting of the Tremp Syncline. (a) Geological map of the area of the South-Pyrenean Basin where the Tremp and Àger synclines are located. Reference sections of the Western Tremp Syncline are marked with Roman numerals: I Campo, II Larra, III Rin, IV Serraduy, V Beranuy, VI Isclés, VII Arén/Areny (map modified after [65]); (b) Stratigraphic proposals for the late Campanian-Paleocene deposits of the Tremp Syncline (modified after [66]). 
The third unit of the Tremp Fm is the 'Vallcebre limestones and equivalents', which is a laterally discontinuous sedimentary unit of limestones with charophytes and Microcodium and which represents coastal lacustrine deposits [43,67]. In the Eastern Tremp Syncline, this unit has been dated as late Danian [56], which would indicate the existence of a disconformity. The K-Pg boundary would accordingly be situated somewhere between the topmost part of the 'Lower Red Garumnian' and the boundary with the 'Vallcebre limestones', with dinosaur-bearing sites lying just a few meters below the Vallcebre limestones ([31,64]; Figure 2). However, up to now, the boundary has never been recognized in the Tremp Syncline within this stratigraphic interval [43]. Finally, the last unit is the 'Upper Red Garumnian', which is a succession of red mudstones, sandstones, and conglomerates, with the occasional presence of paleosoils, gypsum, and limestones, representing fluvial and alluvial environments [43,51]. Its age is constrained in the Tremp Syncline between the Selandian and the late Thanetian $[68,69]$, and at the top of the unit, the Paleocene-Eocene Thermal Maximum has been recognized [70]. It is also worth mentioning the ColmenarTremp Horizon [54], which is a stratigraphic level of caliche paleosoils and gypsum that can be traced across the basin. This horizon overlies the more modern sedimentary units westwards, marking a progressive unconformity within the Garumnian deposits.

The lithostratigraphic schemes used by other authors are indicated in Figure 1b. The 'Grey Garumnian' of Rosell et al. (2001) [43] (Figure 1b) is equivalent to the Posa Fm, whereas the 'Lower Red Garumnian' is equivalent to the Conques and Talarn formations of Cuevas (1992) [51]. Paleogene units also change their names. Thus, the 'Vallcebre limestones and equivalents' are equal to the Sant. Salvador de Toló and Suterranya formations, and the 'Upper Red Garumnian' is equivalent to the Esplugafreda and Claret formations. Furthermore, Cuevas (1992) [51] named as members the limestones intercalated with the mudstones of the Lower and Upper Red Garumnian, including (from older to younger) the Basturs, Tossal d'Oba, and la Guixera members (Figure 1b). Later, Pujalte and Schmitz (2005) [52] and Oms et al. (2016) [42] followed the proposal by Cuevas (1992) [51], with some modifications. Pujalte and Schmitz (2005) define the Claret Conglomerates member within the Claret Fm, and Oms et al. (2016) differentiate the Fumanya Member (lower Maastrichtian tidal flat deposits within La Posa Fm), which is preserved only in the eastern part of the South-Pyrenean Basin.

In the Western Tremp Syncline studied here, there are some sedimentological particularities that sometimes make it difficult to locate the formations and boundaries proposed in the Eastern Tremp Syncline. The boundary between the Conques and Talarn formations (equivalent units to the 'Lower Red Garumnian') is defined by the sharp contact between mudstones and conglomerates, or a swift change of light-colored mudstones to red mudstones and sandstones [51]; however, neither of these contacts can be observed in the Western Tremp Syncline. Moreover, chronostratigraphic data in the eastern part of the Tremp Syncline [63,71] restrict the Conques Fm to the early Maastrichtian (within chron C31r) and the Talarn Fm to the late Maastrichtian (chron C29r), a great part of the late Maastrichtian not being recorded (hiatus between C31r and C29r). By contrast, in the Western Tremp Syncline, the lateral equivalents to these units ('Lower Red Garumnian') are dated to within the late Maastrichtian chrons C30n-C29r [31,62,64,72], thus being the only part of the basin where chron C30n is recorded. According to the lithostratigraphic and depositional model proposed by Ardèvol et al. (2000) [41] and updated by Fondevilla et al. (2016) [63], the Talarn Fm is limited to the eastern part of the basin (see [63], Figure 8c). As a direct correlation is not possible, since part of the succession is overlaid by discordant Neogene conglomerates (Figure 1a), it is quite difficult to determine whether the 'Lower Red Garumnian' in the Western Tremp Syncline corresponds to an upper Maastrichtian Conques Fm or the Talarn Fm. A similar pattern is observed with the 'Vallcebre limestone' of the Western Tremp Syncline, which cannot be directly correlated with the St. Salvador de Toló and Suterranya formations to the east due to their lateral discontinuity. Finally, westwards, the continental deposits of the Tremp Fm pass laterally to the marine Laspún and Navarri formations $[69,73]$. 
3. The Upper Maastrichtian Tetrapod Fossil Record of the Western Tremp Syncline and Its Integration within the Ibero-Armorican Island Record

The sedimentary succession of the Tremp Fm in the Western Tremp Syncline here under study encompasses sedimentary rocks belonging to the 'Grey Garumnian' and 'Lower Red Garumnian', and therefore, the late Maastrichtian between the upper part of chron C30n and chron C29r (Figure 2). The studied area is the part of the Tremp Syncline where the thickest succession of the upper Maastrichtian is preserved (more than $210 \mathrm{~m}$ ). In these upper Maastrichtian sediments, there is a diverse and significant record of vertebrate fossils, including avian and non-avian dinosaurs, crocodylomorphs, testudines, squamates, amphibians, and fishes. More than 1200 fossil remains have been recovered from the hilly outcrops, with 57 different fossil localities identified. In order to facilitate our explanation of the Western Tremp Syncline fossil record, we have clustered the paleontological sites by their closeness to certain reference stratigraphic logs, which are called the Campo (I), Larra (II), Rin (III), Serraduy (IV), Beranuy (V), Isclés (VI), and Areny (VII) sections (Figures 1a, 2 and 3). A table summing up the assemblage from all the sites can be found in the Supplementary Materials Table S1. All the fossils are housed at the Natural Science Museum of the University of Zaragoza (Spain) (MPZ) [74]. 


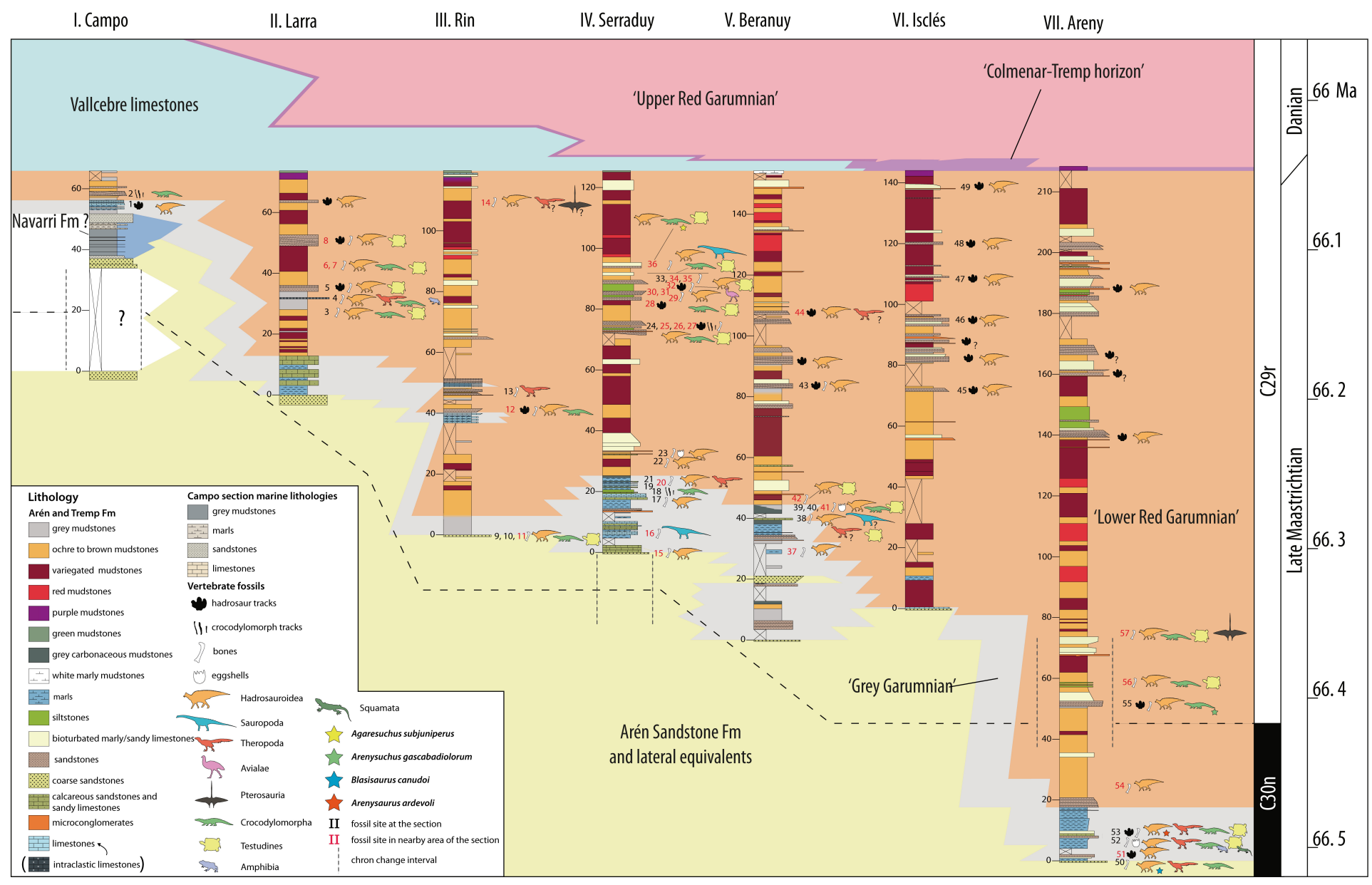

Figure 2. Correlation panel of the Western Tremp Syncline (W-E oriented) with the stratigraphic position of the vertebrate fossil sites: (1) Campo 1, (2) Campo 2, (3) Larra 3, (4) Larra 4, (5) Larra 5, (6) Larra 1, (7) Larra 2, (8) Larra 6, (9) Rin1, (10) Rin2, (11) Barranco Extremadura, (12) Pedregal, (13) Camino Rin 1, (14) Camino Rin 2, (15) Fuente San Cristobal, (16) Femur, (17) Barranco Serraduy 1, (18) Beranuy, (19) 172-i/04/d, (20) 172-i/04/c, (21) 172-i/04/e, (22) Barranco Serraduy 2, (23) 172-i/04/f, (24) Barranco Serraduy 3, (25) 172-i/04/a, (26) Color, (27) Serraduy Norte, (28) Dolor 1, (29) Dolor 2, (30) Dolor 3, (31) 172-i/04/b, (32) Amor 1, (33) Barranco Serraduy 4, (34) Barranco Serraduy 5, (35) Amor 2, (36) Amor 3, (37) Fornons 1 , (38) Camino Fornons 1, (39) Camino Fornons 2, (40) Veracruz 1, (41) Fornons 2, (42) Sierra del Sis 1, (43) Sierra del Sis 2, (44) Fornons 3, (45) Isclés 1, (46) Isclés 2, (47) Isclés 3, (48) Isclés 4, (49) Isclés 5, (50) Blasi 1, (51) Areny 1, (52) Blasi 2a and 2b, (53) Blasi 3, (54) Blasi 3, 4, (55) Elias, (56) Blasi 4, (57) Blasi 5 (Larra log is modified from Puértolas Pascual et al. (2018), magnetostratigraphic data from $[31,64,75]$. 


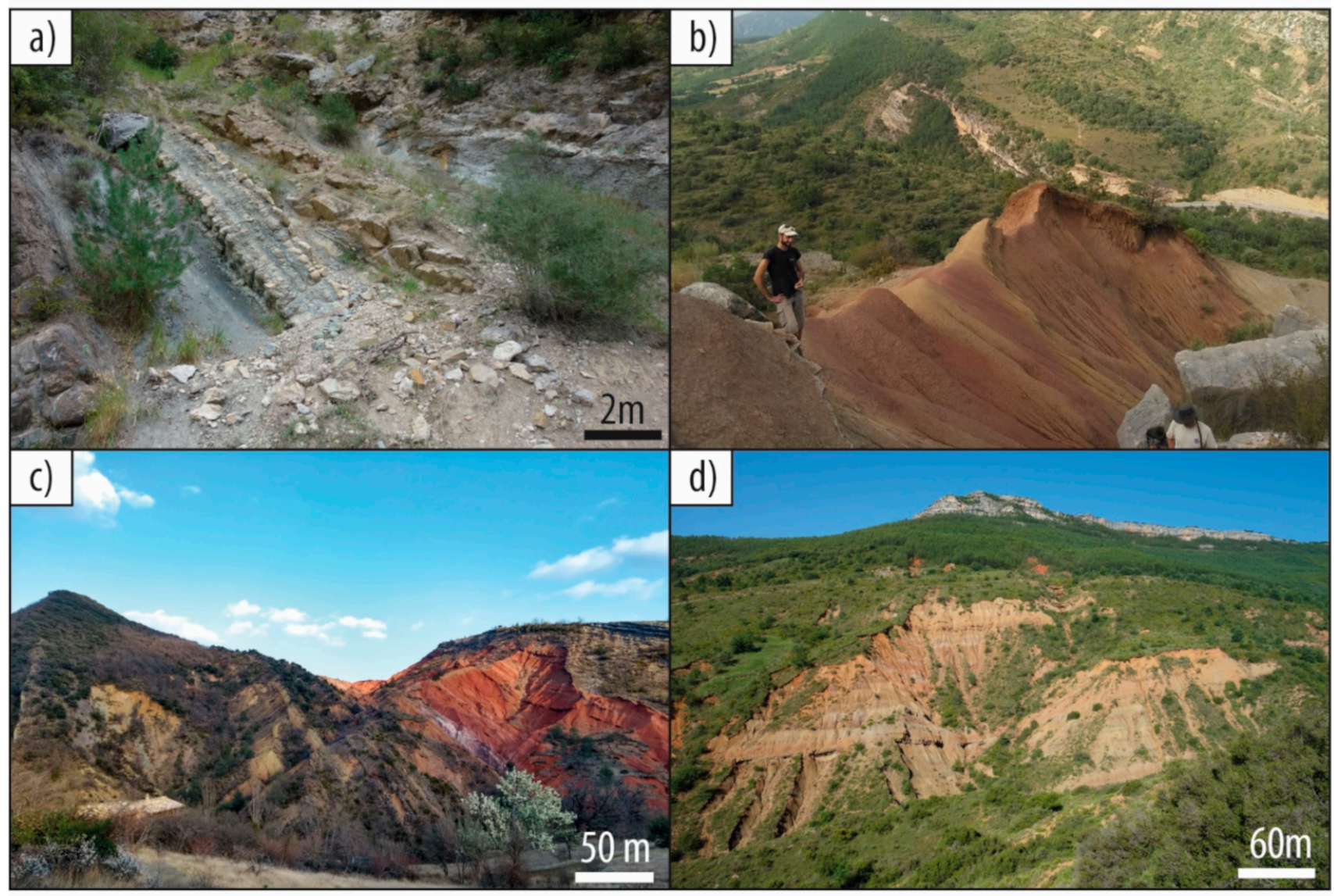

Figure 3. Upper Maastrichtian outcrops of the Western Tremp Syncline (Aragón, NE Spain). (a) Campo section (I); (b) Serraduy section (IV); (c) Isclés section (VI); (d) Arén/Areny section (VII).

\subsection{Dinosauria}

\subsubsection{Hadrosauroidea}

Hadrosauroid dinosaurs are the clade of Cretaceous ornithopods with the most abundant fossil record, especially in the Northern Hemisphere. In Europe, the best record of hadrosauroids has been recovered from France and Spain. In Spain, it is concentrated principally in the South-Pyrenean Basin (the provinces of Huesca and Lleida, NE Spain) $[23,62,75-81]$.

In the Western Tremp Syncline, hadrosauroids are recorded in the upper Maastrichtian sediments of the Arén Sandstone Fm and the 'Grey and Lower Red Garumnian' of the Tremp Fm; these are among the youngest non-avian dinosaurs in the world [64]. The first hadrosauroid bones were found in the 1990s near the locality of Arén (Areny in Catalan) (Huesca, Aragón) by the geologists Lluís Ardèvol and Fabián López Olmedo during geological mapping work. Early work on several sites (Blasi 1 to 5 and Blasi 3,4) by a multidisciplinary team yielded fossil remains of indeterminate euhadrosaurids together with bones and eggshells of several dinosaurs and other terrestrial and aquatic vertebrates [72] (Figure 2). Later studies on specimens from the Blasi 1 and Blasi 3 sites resulted in the erection of two lambeosaurine hadrosaur species: Blasisaurus canudoi Cruzado-Caballero, Pereda-Suberbiola, and Ruiz-Omeñaca 2010a [82] (Figures 3 and 4b) 
and Arenysaurus ardevoli Pereda-Suberbiola, Canudo, Cruzado-Caballero, Barco, LópezMartínez, Oms and Ruiz-Omeñaca [62,83] (Figures 3 and 4a,c). Both sites fall within the upper part of chron C30n [62]. These two species are recovered within Arenysaurini, which is a recently erected clade of lambeosaurines from Europe [84].

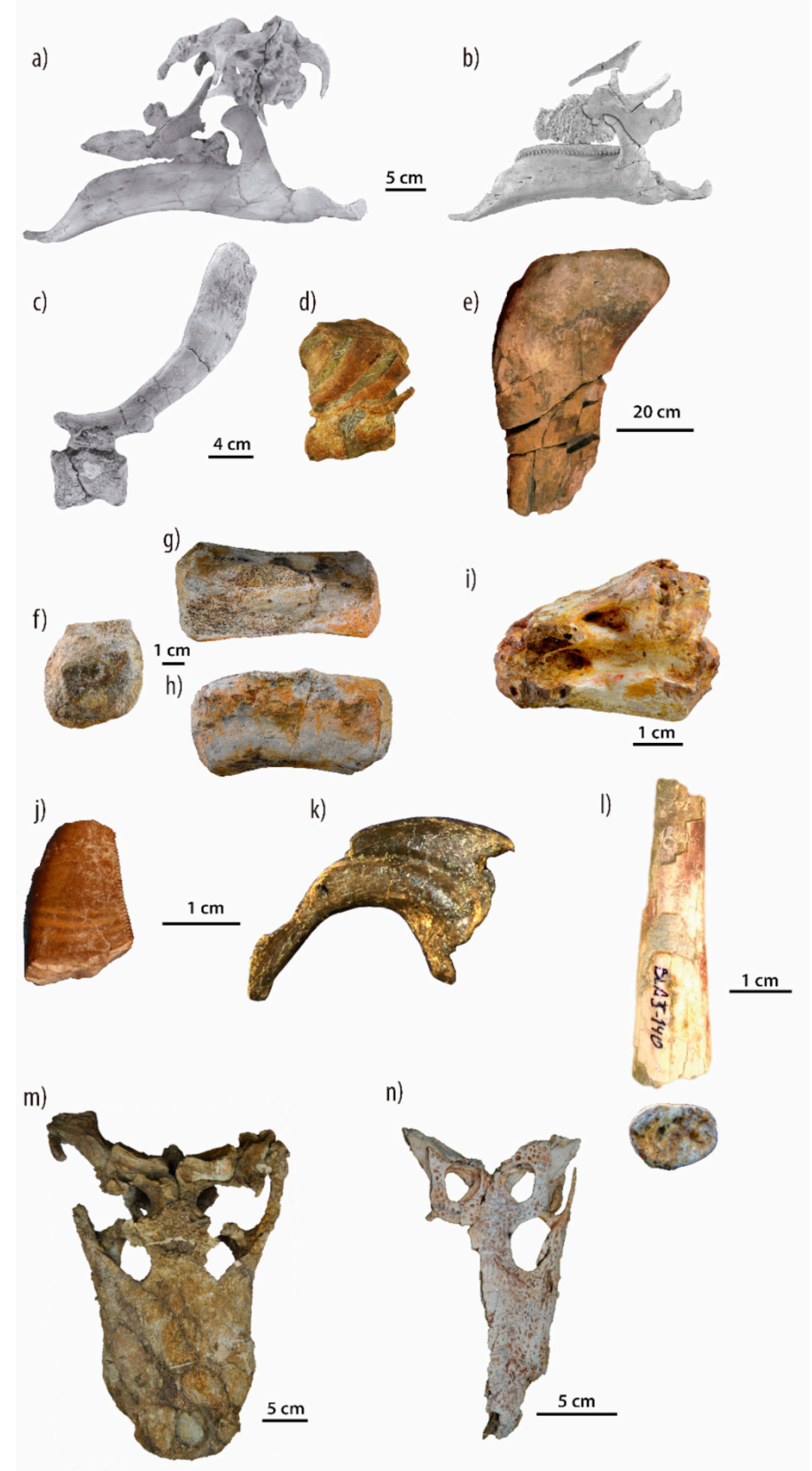

Figure 4. Main tetrapod remains from the Western Tremp Syncline. (a) Cranial elements of Arenysaurus ardevoli (MPZ2008/17, MPZ2008/256, MPZ2008/258, MPZ2008/259, MPZ2011/01), in left lateral view (modified from CruzadoCaballero et al., 2013); (b) cranial elements of Blasisaurus canudoi (MPZ 99/664, MPZ 99/665, MPZ99/666a, MPZ99/666b, MPZ99/667, MPZ 2009/348), in left lateral view; (c) mid-caudal vertebra of Arenysaurus (MPZ204/480), in left lateral view (modified from Cruzado-Caballero et al., 2013); (d) articulated mid-caudal vertebrae of the small hadrosaurid from Serraduy (MPZ 2013-371), in left lateral view; (e) femur (proximal end) of Titanosauria indet. from Serraduy (MPZ 99/143), in posterior view (modified from Puértolas-Pascual et al., 2018); (f-h) posterior caudal vertebra of Titanosauria indet. (MPZ2021/1), in anterior view (f); dorsal view (g); left lateral view (h); (i) cervical vertebra of Ornithuromorpha indet. (MPZ 2019/264), in left lateral view; (j) cf. Arcovenator tooth (MPZ 2017/804), in lingual view; (k) pedal ungual II of Dromaeosauridae indet. (MPZ 2019/196), in lateral view; (1) fragmentary bone of Pterosauria indet. (MPZ 2021/54) (note the thin cortex in the transverse section); (m) skull of Agaresuchus subjuniperus (MPZ 2012/288), in dorsal view; (n) skull of Arenysuchus gascabadiolorum (MP Z2011/184), in dorsal view. 
In addition to this, other remains of indeterminate hadrosaurids and euhadrosaurids have been described from the Blasi sites [76,78,85-87]. The findings from these sites have also led to the first description of a pathological bone from a hadrosaurid in Spain [88] and the first paleo-neuroanatomical description of a European lambeosaurine, Arenysaurus ardevoli [89]. Recent studies on the paleohistology of the hadrosauroids from the Blasi sites reveal the presence of hadrosaurid individuals at different ontogenetic stages, including early and late juveniles, subadults, and mature adults [90,91]. New areas with hadrosaurid remains have been found in the vicinities of Serraduy (Isábena, Huesca, Aragón) and Beranuy (Huesca, Aragón) (Figure 2) [23,64,77,79,92-94]. The new sites are characterized by the presence of fossil remains of the smallest adult hadrosaurids (maybe affected by insular dwarfism) from Europe, which coexisted alongside larger hadrosaurids [79] (Figure 4d).

This rich osteological record of hadrosauroids in the Western Tremp Syncline is complemented by several track sites. These tracks appear in several levels from Arén to Campo (Huesca, Aragón), with large ornithopod footprints, many of which have been referred to the ichnogenus Hadrosauropodus [31,64,95,96] (Figures 3 and 5a,b), spanning from the top of chron C30n into chron C29r. Recently, in the Blasi 2B site, eggshells attributable to hadrosaurid dinosaurs have been tentatively referred to Spheroolithus aff. europaeus Sellés, Vila, Galobart 2014 [97,98].

\subsubsection{Sauropoda}

The sauropod remains in the Western Tremp Syncline are very scarce compared to those in the eastern part, where titanosaur bones, eggshells, and tracks are moderately abundant $[33,71,99]$. A remarkable specimen is the proximal half of a femur (MPZ 99/143) that probably corresponds to a large and indeterminate titanosaur [71,100] (Figure 4e). MPZ 99/143 was recovered northwest of the town of Serraduy, in the 'Grey Garumnian' unit ('Femur' site in Figure 2). Interestingly, the femur was originally correlated to the top of chron $\mathrm{C} 30 \mathrm{n}$, but the chronostratigraphical data indicate that this fossil lies within chron C29r $[31,64]$. Thus, this femur is one of the youngest records of titanosaurian sauropods in the Ibero-Armorican island, along with those recorded in fossil sites in the Catalonia region, including the 'Molí del Baró-2' femur [71], the vertebra from 'El Portet' site [101], and the skin impressions and footprints from the 'Mirador de Vallcebre' [102]. In addition, Cruzado-Caballero et al. (2012) [77] reported a caudal vertebral centrum that was found in the 'Lower Red Garumnian' unit near Serraduy and Beranuy. The caudal vertebra (MPZ 2021/1) is from the 'Barranco Serraduy 4' site (Serraduy) (Figures 2 and 4f-h), which is situated stratigraphically above the 'Femur' site, making it the youngest evidence of sauropods in the Western Tremp Syncline. MPZ 2021/1 is a slightly deformed centrum from a posterior caudal vertebra, which is elongated craniocaudally and compressed dorsoventrally. It is amphiplatyan, with both articular surfaces flat to slightly concave and with a rounded contour (Figure $4 \mathrm{f}, \mathrm{h}$ ). In anteroposterior view, the centrum has a subcircular outline (Figure 4f). Its ventral surface is slightly concave and lacks chevron facets (Figure 4h). Together with its length and the absence of transverse processes, this indicates that it was situated distally in the caudal series [103]. The neural arch is not preserved, but its attachment facets can be observed in the anterior area of the centrum (Figure $4 \mathrm{~g}$ ), which is a synapomorphy of Titanosauriformes [104]. The amphiplatyan condition in the middle and posterior caudal vertebrae is plesiomorphic within Titanosauria $[104,105]$. Some basal titanosaurs show this condition, as is the case of Andesaurus [106,107] or the distalmost vertebrae of Lirainosaurus [103]. Therefore, we tentatively refer it to Titanosauriformes indet., but for the reasons mentioned above, its ascription to Titanosauria cannot be ruled out. 

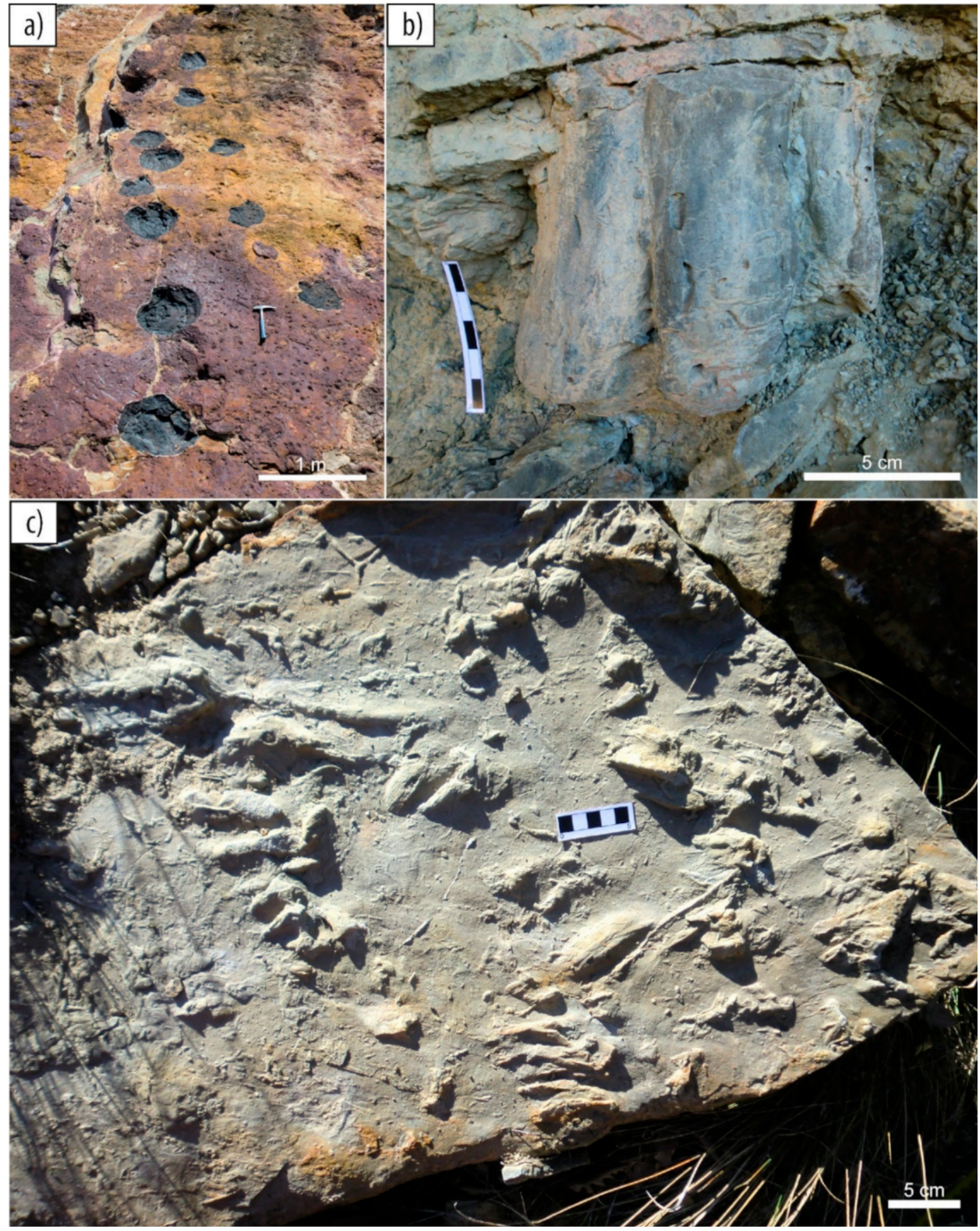

Figure 5. Tetrapod tracks from the Western Tremp Syncline. (a) Hadrosauropodus trackway from the Areny 1 site; (b) foot cast of a hadrosaurid dinosaur from the 172-i/04/a site; (c) crocodylomorph tracks from the Serraduy Norte site.

\subsubsection{Theropoda}

Theropod fossils are scarce in the Western Tremp Syncline, and these are mainly represented by teeth, eggshells, and some isolated bones. Torices et al. (2015) [108] describe several teeth from the Blasi sites of Arén/Areny (Figure 2). They identify one 
morphotype as Coelurosauria indet. (MPZ 98/79 to 82) and three morphotypes belonging to maniraptoran theropods, including Richardoestesia sp. (MPZ 98/72 to 74, MPZ 2004/7), cf. Paronychodon (MPZ 98/76 to 78), and Dromaeosauridae indet. (MPZ 2004/6). Finally, they describe two different morphotypes of large teeth whose assignation is problematic and that are referred to Theropoda indet. 1 (MPZ 98/67, MPZ 2004/3 to 5, 8) and Theropoda indet. 2 (MPZ 98/68), although a possible relation with neoceratosaurs is suggested. In fact, these two morphotypes were identified by Pérez-García et al. (2016) as cf. Arcovenator [109], which is an abelisaurid species from the Campanian of southern France. The Blasi sites 1, 2, and 3 are dated to within chron C30n [62] (Figure 2). Two more theropod teeth have been described from the fossil sites of 172-i/04/e (Serraduy) and Larra 4 (Valle de Lierp) [64]. The first tooth (MPZ 2017/804) (Figure 4j) is large and resembles the Theropoda indet. morphotype 1 (cf. Arcovenator) from Torices et al. (2015) [108], and the second one has been identified as Coelurosauria indet. Both sites are situated in outcrops of the 'Lower Red Garumnian' dated to within chron C29r [64].

Postcranial fossils of theropods are not very common and are usually fragmentary. A pedal ungual II (MPZ 2019/196) (Figure 4k) and the proximal part of an ulna (MPZ 2019/194) from a dromaeosaurid theropod were found at the Larra 4 site (Valle de Lierp, Huesca, Aragón, Spain) (Figure 2) [93]. Other sites in the Serraduy area have yielded fragmentary remains of indeterminate theropods (Figure 2). As regards avian theropods, a cervical vertebra from a large ornithuromorph bird has recently been described from the Tremp Fm outcrops between Serraduy and Biascas de Obarra (Beranuy, Huesca) (MPZ 2019/264) [110] (Figures 2 and 4i). It has been dated as uppermost Maastrichtian (C29r) [64] and represents the youngest record of a Mesozoic bird in Europe.

Up to now, theropod eggshells have only been found in the site Blasi 2B ('Grey Garumnian' at Arén/Areny, C30n; Figure 2). This site has a diverse theropod eggshell assemblage, which was briefly described by López-Martínez et al. (1999) [111]. The authors recognized up to six different types of prismatoolithid eggshells, whereas more recent research [98,112] recognized at least four different types (Figure 6a,b), including two different morphotypes attributable to the oogenus Pseudogeckoolithus, which has recently been referred to maniraptoran theropods [113]. Further research is necessary to ascertain the exact number of theropod ootaxa present at Blasi 2B.

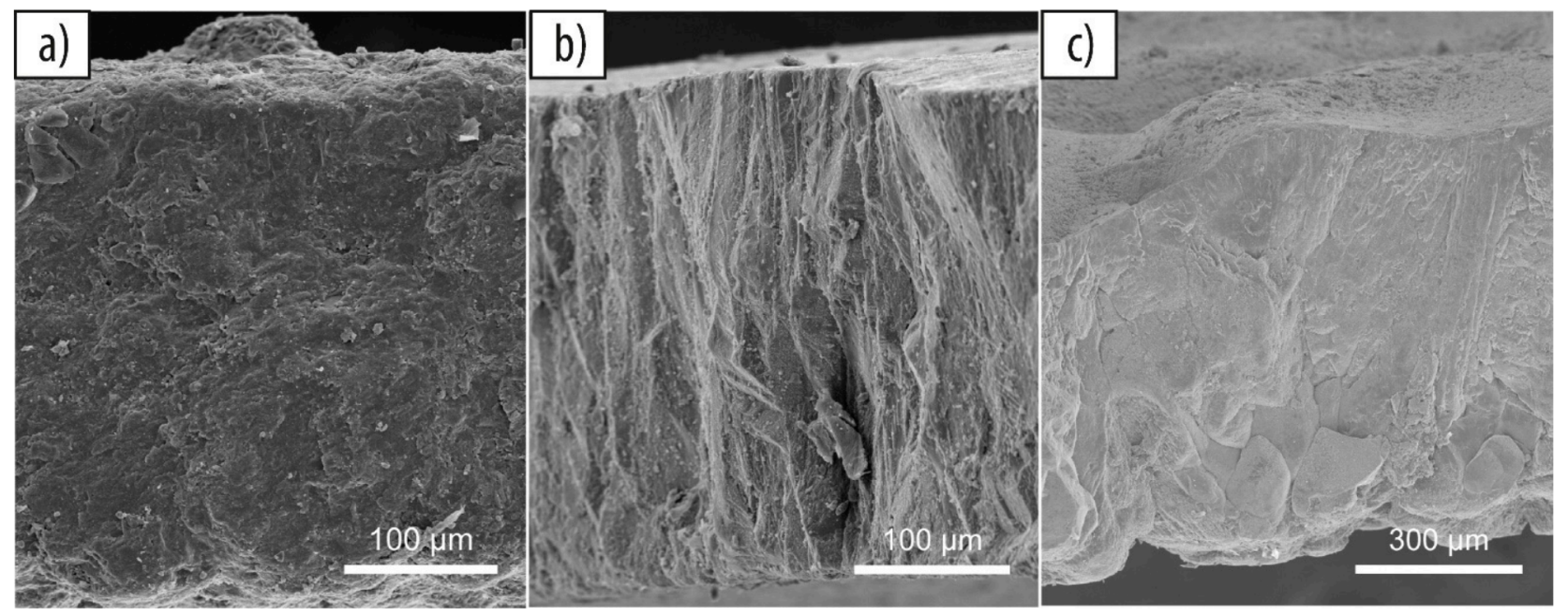

Figure 6. Tetrapod eggshells from the Western Tremp Syncline. (a) Pseudogeckoolithus sp. from the Blasi 2B site; (b) Prismatoolithidae indet. from Blasi 2B; (c) Krokolithes sp. from the Veracruz 1 site.

\subsection{Pterosauria}

The presence of pterosaurs in the upper Maastrichtian of the Tremp Syncline has only been reported from the site of Torrebilles-2 in the Eastern Tremp Syncline, within chron 
C29r [114]. In the Western Tremp Syncline, Puértolas-Pascual et al. (2018) [64] reported a possible mandible of a pterosaur from the upper part of the 'Lower Red Garumnian' near Serraduy (Isábena). This specimen has been reexamined, and although its identification as a dentary has been refuted, its affinity to a pterosaurian bone cannot be ruled out. However, until a future study identifies this bone more precisely, it cannot be assigned to Pterosauria. Nevertheless, we have identified a fragment of a long bone from the Blasi 5 site (Figures 2 and 41) that shows a very thin cortex (thinner than the pterosaur bones from Barranc de Torrebilles-2 [114]) and is hollow inside. This bone could be the first pterosaur fossil identified in the Western Tremp Syncline. Blasi 5 is situated in the upper part of the 'Lower Red Garumnian' and is dated to within chron C29r (Figure 2) [62].

\subsection{Crocodylomorpha}

The crocodylomorph record in the Western Tremp Syncline is dominated by eusuchians. Two skulls belonging to two different genera have been identified. The first one is Arenysuchus gascabadiolorum Puértolas, Canudo, Cruzado-Caballero 2011 [115] (MPZ 2011/184) (Figure 4n), from the Elias site near Arén/ Areny ('Lower Red Garumnian', C29r, Figure 2). Phylogenetically, MPZ 2011/184 was initially placed within Crocodyloidea (crown-group Crocodylia) [115], but later cladistic studies have situated it as a more basal eusuchian within Allodaposuchidae [116-120]. The second species is the allodaposuchid Agaresuchus subjuniperus Puértolas-Pascual, Canudo, Moreno-Azanza 2014 [121] (MPZ 2012/288) (Figure 4m). MPZ 2012/288 was initially identified as a member of the genus Allodaposuchus [121], but it was later reassigned to Agaresuchus [119]. This crocodylomorph comes from the Amor 3 site near the town of Serraduy, from one of the uppermost levels of the 'Lower Red Garumnian' (C29r, Figure 2). As such, it could be one of the youngest crocodylomorphs on the Ibero-Armorican island before the K-Pg extinction. In addition, allodaposuchids are also represented by isolated teeth in several sites throughout the C30n-C29r interval (Figure 2) $[23,64,93,94,122]$. All these teeth are conical with pointed crowns, showing the typical morphology of crocodylomorphs with a generalist diet. These dental morphologies have been observed in several allodaposuchid species from the Late Cretaceous of Europe (e.g., [122]). As the presence of other crocodylomorph clades with generalist dentition cannot be ruled out, these teeth were assigned to cf. Allodaposuchidae, since this is the most abundant clade in this region and time interval.

Gavialoidea is another clade of crocodylomorphs that may be present in the upper Maastrichtian of the Western Tremp Syncline. A few elongated conical teeth with basiapical ridges have been assigned to cf. Thoracosaurus. These are restricted to the transitional environments of the Arén Fm and the 'Grey Garumnian' unit of the Tremp Fm close to Arén/Areny, Beranuy and Serraduy (Figure 2) [23,64,122].

Hylaeochampsidae are represented by tribodont teeth from the Blasi 2B site, which were identified as cf. Acynodon (MPZ-2017/1137) [23,64,72,122]. The eusuchian record is augmented by teeth, osteoderms, and vertebrae from the Blasi and Serraduy sites, whose taxonomical position within Eusuchia is difficult to assign with precision. They are accordingly identified as Eusuchia indet. [23,64,72,122] (Figure 2).

López-Martínez et al. (2001) [72] pointed out the presence of "trematochampsid"-like and alligatoroid teeth from the sites of Blasi 1, 2, and 3 (Figure 2). However, although the authors did not provide pictures or specimen numbers, the morphotypes in question probably correspond to more recently erected taxa that had not been described at the time of publication of that paper. The "trematochampsid"-like teeth may correspond to non-eusuchian crocodylomorphs more typical of the Late Cretaceous of Europe, such as Sabresuchus or Doratodon, and the alligatorid teeth probably correspond to allodaposuchids. In addition, Blanco et al. (2020) [122] mentioned the presence of a conical tooth (MPZ 2010/948) with enamel striations and crenulated carinae assigned to Mesoeucrocodylia indet.

There are also crocodylomorph eggshells from the Blasi 2 site (upper part of C30n, Figure 2). These were first reported as megaloolithid eggshells [111], but they were 
later [123] described as having a crocodyloid morphotype and were identified as Krokolithes sp. Hirsch, 1985 [124], implying that these eggs were laid by crocodylomorphs. Something similar has occurred with the eggshells found at the Veracruz 1 site close to Biascas de Obarra, (Beranuy section, C29r, Figure 2), which were first identified as hadrosaurid eggshells [94] (Figure 6c), but after a more thorough study, their crocodylomorph affinities have been ascertained, and a description is in preparation.

Finally, the crocodylomorph record also includes several swimming and plantigrade tracks from the Serraduy, Beranuy, and Campo outcrops, all within chron C29r $[23,125,126]$ (Figures 2 and $5 \mathrm{c}$ ). This is the youngest record of crocodylomorph tracks in Europe. These tracks represent digit scratch marks produced by the manus and pes of buoyant crocodylomorphs, and they have been assigned to the ichnogenus Characichnos. One pedal impression has been assigned to cf. Crocodylopodus, and although its assignation cannot be confirmed with certainty due to the scarce material, this is the youngest occurrence of this ichnotaxon [125].

\subsection{Testudines}

Testudines are represented mainly by disarticulated plates of the carapace or the plastron, which appear at most of the paleontological sites from the topmost part of the Arén Fm to the upper levels of the 'Lower Red Garumnian' (Figure 2). Most of these remains show fine ornamentation comprising thin dichotomic grooves, which is a distinctive character of the bothremydids [127]. Among these remains, Murelaga and Canudo (2005) [128] describe several plates from the Blasi sites near Arén/Areny (Figure 2), including nuchal, pleural, and peripheral plates, a hyoplastron, a hypoplastron, and a xiphiplastron from bothremydid turtles. At the site of Rin 2, near the town of Serraduy (Isabena municipality), situated in the topmost part of the Arén Fm, Murelaga and Canudo (2005) [128] describe a xiphiplastron and a mesoplastron from a bothremydid. Pérez-Pueyo et al. (2019a, 2019b) [93,94] also describe indeterminate plates from this kind of turtle from the Larra 4 (Valle de Lierp) and Veracruz 1 (Biascas de Obarra, Beranuy) sites (Figure 2). Thus, the record of this group of pleurodiran turtles extends from the upper part of chron C30r to near the K-Pg boundary interval. It is also important to note that Murelaga and Canudo (2005) [128] identify a peripheral plate from a solemydid turtle from the Blasi 2 site (Figure 2). This shows its characteristic vermiculate ornamentation, although it is not well preserved.

\subsection{Amphibia and Squamata}

The Blasi 2 site has yielded a rich microvertebrate fossil assemblage, which includes the bones of small tetrapods, mainly amphibians and squamates [129] (Figure 2). Amphibian remains dominate, with at least one albanerpetontid (resembling the North American taxon Albanerpeton nexuosum) and two anurans, a discoglossid and a palaeobatrachid. The squamate remains comprise at least two undetermined lizards, one anguid lizard, and a snake. Blasi 2B is dated to the top of chron C30n in the 'Grey Garumnian' and is the only well-studied microvertebrate site in the Western Tremp Syncline. However, it is noteworthy that the Larra 4 site (Valle de Lierp) (C29r) has yielded remains from discoglossid amphibians [64], making it the youngest microvertebrate site in the Western Tremp Syncline.

\subsection{The Tetrapod Fossil Record from the Upper Maastrichtian of the Ibero-Armorican Island}

The tetrapod fossil record of the Western Tremp Syncline adds several unique taxa to the late Maastrichtian assemblages of the Ibero-Armorican island, yielding the youngest record of some groups prior to the Paleocene. To date, the upper Maastrichtian record of the Ibero-Armorican island is limited to the South Pyrenean Basin in northeast Spain; the Sobrepeña Fm, Torme Fm, and equivalent outcrops in northwest Spain [130,131]; east Spain near Tous (Valencia) [132,133]; and the Haute-Garonne and Aude departments in southern France [33,134]. During the Maastrichtian, the dinosaur faunas underwent a change in dominant herbivores during the so-called "Maastrichtian Dinosaur Turnover" [33,34,135]. 
During the early Maastrichtian, ecosystems were inhabited by rhabdodontid ornithopods, titanosaurian sauropods and ankylosaurs, whereas in the late Maastrichtian, these communities were replaced by hadrosaurid ornithopods and new titanosaurian forms. However, nodosaurid ankylosaurians still persisted up to chron C30r, coexisting with these new assemblages for nearly 2 Myr [33].

Lambeosaurine hadrosaurids were present in the Ibero-Armorican island from the late early Maastrichtian, mostly recorded from the Pyrenees (Spanish and French). The lambeosaurine from Els Nerets (Vilamitjana, Catalonia, NE Spain) is the oldest evidence of hadrosaurids in Europe, which was dated to within chron C31r [81]. Lambeosaurines are also present within chron C29r, with some fossils falling very close to the K-Pg boundary. At present, there are five species of lambeosaurine hadrosaurids described from the region, comprising Adynomosaurus from the Costa de Les Solanes site (Basturs, Catalonia) [136], Arenysaurus [62], Blasisaurus [82] from Areny and Blasi sites (Ribagorza, Aragón, NE Spain), Pararhabdodon from the Sant Romà d'Abella site (Lleida, Catalonia, NE Spain) [80,137-139], and Canardia from the Lacarn and Tricoute sites (Haute-Garonne, southern France) [80]. Additional hadrosauroid remains include the aforementioned lambeosaurinae from Els Nerets [81] and other indeterminate lambeosaurines from Basturs Poble and Les Llaus (Lleida, Catalonia) [80,140-142]; a non-hadrosaurid hadrosauroid from Fontllonga-R (Fontllonga, Catalonia, NE Spain) [75]; an indeterminate euhadrosaurid from Blasi 3,4 [78]; and a small hadrosaurid from Serraduy [79]. Outside the Pyrenees, there is a dentary from La Solana (Tous, Valencia, E Spain) that has been identified as belonging to an indeterminate hadrosaurid $[75,143]$. Finally, there is a hadrosauroid femur from the Albaina site (Laño, Condado de Treviño, Burgos, NW Spain) [144]. With six to twelve taxa, hadrosauroids are the most speciose clade of dinosaurs in the Tremp Basin, five to eight of them being lambeosaurine hadrosaurids (Table 1, Figures 7 and 8).

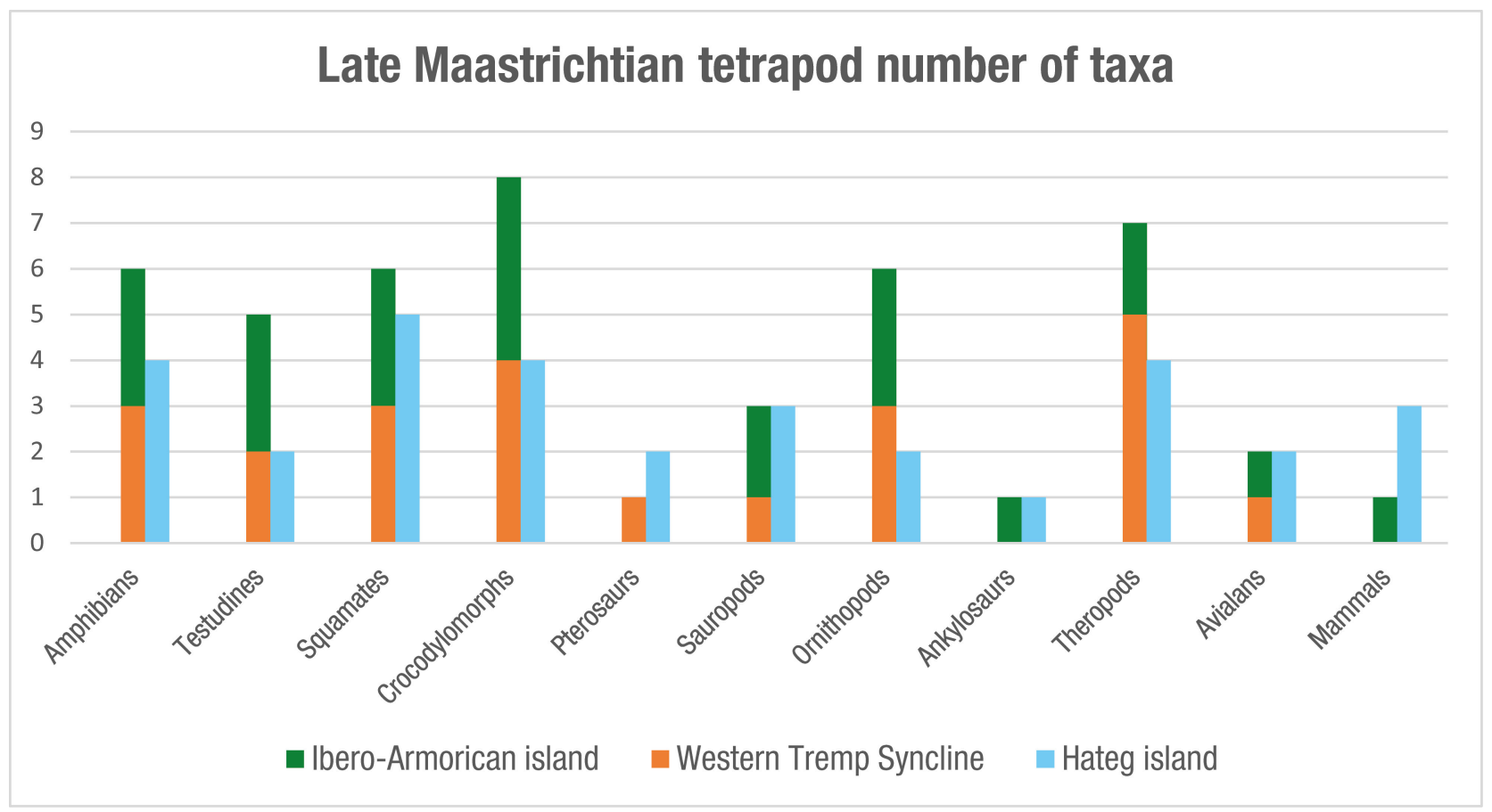

Figure 7. Bar chart with the minimum number of tetrapod taxa (genera) present in the Ibero-Armorican island and Haţeg island during the late Maastrichtian. 
Table 1. Number of tetrapod taxa present on the Ibero-Armorican and Hateg islands during the late Maastrichtian. Red numbers mark possible additional taxa.

\begin{tabular}{|c|c|c|c|}
\hline Taxon & $\begin{array}{l}\text { Ibero-Armorican } \\
\text { Island }\end{array}$ & $\begin{array}{l}\text { Western Tremp } \\
\text { Syncline }\end{array}$ & Hațeg Island \\
\hline Amphibia & 6 & 3 & 4 \\
\hline Anura & 4 & 2 & 3 \\
\hline Albanerpetontidae & 1 & 1 & 1 \\
\hline Salamandridae & 1 & - & - \\
\hline Squamata & $6+2 ?$ & $3+2 ?$ & 5 \\
\hline 'Scincomorpha' & 1 & $1 ?$ & 1 \\
\hline Anguimorpha & 1 & 1 & 1 \\
\hline Teiioidea & 1 & - & 1 \\
\hline Borioteiioidea & - & - & 1 \\
\hline Scleroglossa & 1 & 1 & - \\
\hline Iguanidae & 1 & $1 ?$ & - \\
\hline Amphisbaenia & $1 ?$ & - & - \\
\hline Varanoidea & $1 ?$ & - & - \\
\hline Alethinophidia & 1 & 1 & 1 \\
\hline Testudines & 5 & 2 & 2 \\
\hline Meiolaniformes & - & - & 1 \\
\hline Pan-Pleurodira & 3 & 1 & 1 \\
\hline Pan-Cryptodira & 2 & 1 & - \\
\hline Crocodylomorpha & 8 & 4 & 4 \\
\hline Notosuchia (Doratodon) & 1 & - & 1 \\
\hline Neosuchia ('Atoposauridae') & 1 & - & 1 \\
\hline $\begin{array}{l}\text { Basal Eusuchia } \\
\text { (Allodaposuchidae) }\end{array}$ & 4 & 2 & 1 \\
\hline Basal Eusuchia & & & \\
\hline $\begin{array}{l}\text { (Hylaeochampsidae, cf. } \\
\text { Acynodon) }\end{array}$ & 1 & 1 & 1 \\
\hline Eusuchia (Gavialoidea) & 1 & 1 & - \\
\hline Pterosauria & 1 & 1 & 2 \\
\hline Azhdarchidae & 1 & 1 & 2 \\
\hline Dinosauria & $18+1 ?(6)$ & $10(1)$ & $12+1 ?(3)$ \\
\hline Sauropoda & 3 & 1 & 3 \\
\hline Titanosauria & 3 & 1 & 3 \\
\hline Theropoda & $8+1 ?$ & 6 & $6+1 ?$ \\
\hline Alvarezsauridae & - & - & $1 ?$ \\
\hline Abelisauroidea & 1 & 1 & - \\
\hline Coelurosauria indet. & 1 & 1 & - \\
\hline Maniraptora & 5 & 3 & $3(2)$ \\
\hline $\begin{array}{l}\text { Paraves with uncertain } \\
\text { affinities (Balaur, Elopteryx) }\end{array}$ & - & - & $1(1)$ \\
\hline Enantiornithes & $1 ?$ & - & 1 \\
\hline Ornithuromorpha & 1 & 1 & 1 \\
\hline Ornithopoda & $6(6)$ & $3(1)$ & 2 \\
\hline Rhabdodontidae & - & - & 1 \\
\hline Hadrosauroidea & $6(6)$ & $3(1)$ & 1 \\
\hline Ankylosauria & 1 & - & 1 \\
\hline Nodosauridae & 1 & - & 1 \\
\hline Mammalia & $1 ?$ & & 3 \\
\hline Multituberculata & - & - & 3 \\
\hline Theria & $1 ?$ & - & - \\
\hline
\end{tabular}

Ankylosaurs are represented during the late Maastrichtian by isolated and fragmentary material referred to nodosaurids from several sites in the Southern Pyrenees within the Lleida province (Catalonia, NE Spain), including Els Nerets [145], Fontllonga-6 [111], and Biscarri [146]. They are also present at the Lestaillats site, in the Petite Pyrénées (Haute- 
Garonne, southern France) [134]. Their last occurrence is documented at the Fontllonga-6 and Lestaillats sites, dated to within chrons C30r and C30n (Figure 8).

Titanosaurs from the upper Maastrichtian of the Ibero-Armorican island consist mainly of three undetermined but distinct taxa represented by three femur morphotypes [71] (Figures 7 and 8). The femur from Serraduy corresponds to a large titanosaur, whereas the other two femora represent small-medium titanosaurs. Although not formally described, these titanosaurs represent different taxa from those of the early Maastrichtian assemblage [71] This distinction is additionally supported by the distinct ootaxa association reported from the pre- and post-turnover assemblages, respectively [33,99].

Theropods from the late Maastrichtian of the Ibero-Armorican island are mainly abelisaurids and maniraptorans $[64,93,108,147,148]$, and they have been found only in the South-Pyrenean Basin. Due to their fragmentary and incomplete nature, the number of taxa is difficult to determine. Based on tooth morphotypes from the Southern Pyrenees, at least one abelisaurid taxon inhabited the island during the late Maastrichtian (Theropoda indet. 1 and 2 or cf. Arcovenator; [108]) (Figures 7 and 8). Maniraptorans are also represented mainly by teeth from the Southern Pyrenees, with at least three taxa identified in this way (Richardoestesia, Paronychodon, and Dromaeosauridae indet. from [108]), and by the troodontid Tamarro insperatus Sellés, Vila, Brusatte, Currie and Galobart 2021 [149], which were recently described on the basis of skeletal remains (Table 1, Figures 7 and 8). However, the real abundance of theropods is hard to establish, since there are several fragmentary skeletal remains attributable to undetermined dromaeosaurids, and an oological record comprising several ootaxa of maniraptoran-like eggshells, including Prismatoolithus trempii Sellés, Vila, Galobart 2014 [150], and Pseudogeckoolithus Vianey-Liaud and López-Martínez 1997 [151] $([98,113,150])$. Avialan dinosaurs are represented by the giant ornithuromorph bird from Beranuy [110] and a putative enantiornithine from southern France [152] (Table 1, Figures 7 and 8). 


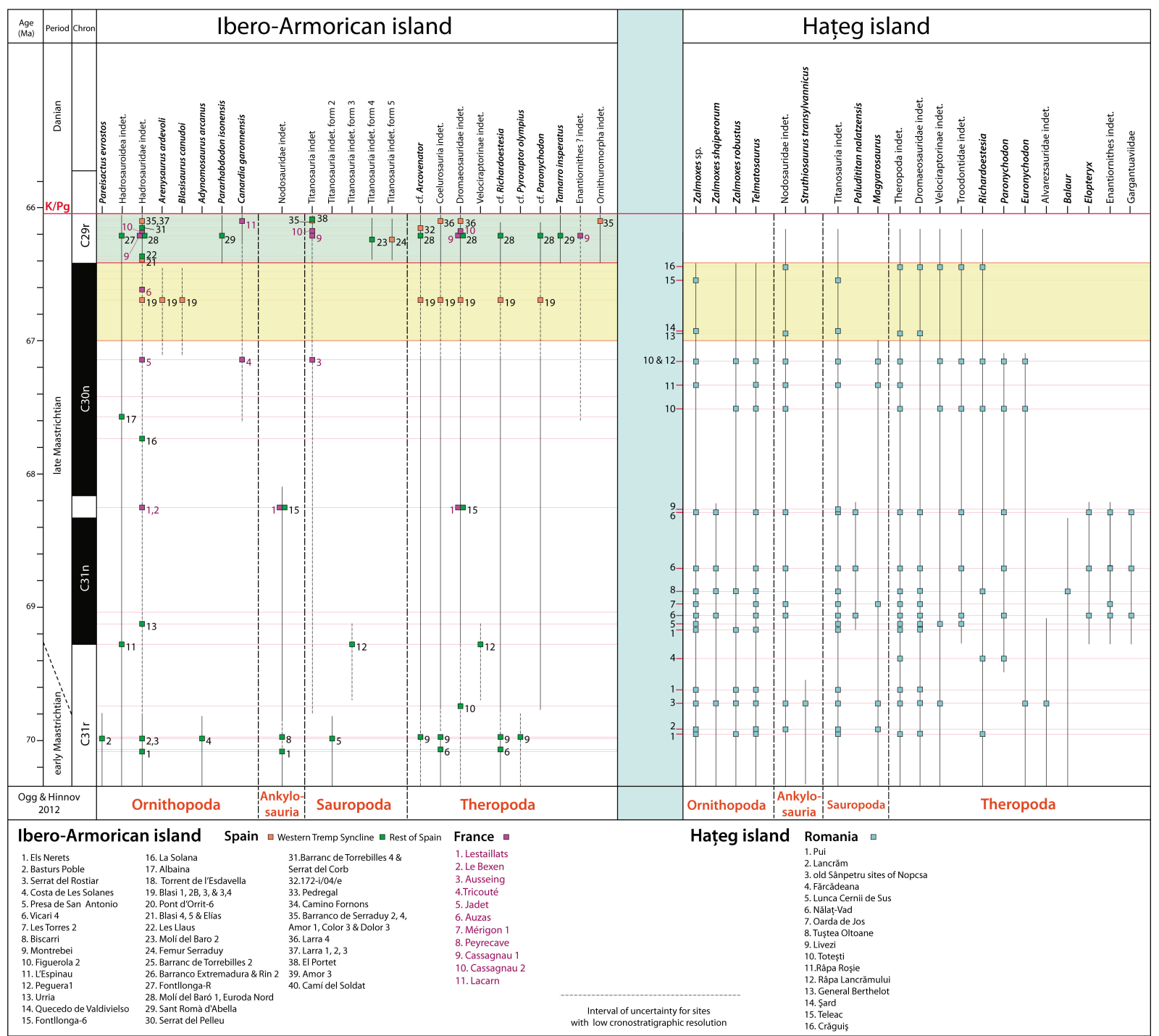

Figure 8. Dinosaur groups and species occurrences in the Ibero-Armorican island and Haţeg island during the late Maastrichtian. Haţeg island data are based on [32] with updated information. The yellow band marks the temporal interval used for comparison, whereas the green band marks the last $\approx 350$ ka of the Maastrichtian, with a record only in the Ibero-Armorican island. Magnetochronostratigraphic scale based on [153] and calibration for the K-Pg boundary based on [28].

The pterosaur record in the late Maastrichtian is scarce, with some isolated and fragmentary bones from the Pyrenees of France [154-156] and Spain [114] and from the upper Maastrichtian outcrops near Valencia (Spain) [157,158] (Figure 9). All of them have been identified as belonging to undetermined giant azhdarchids. 


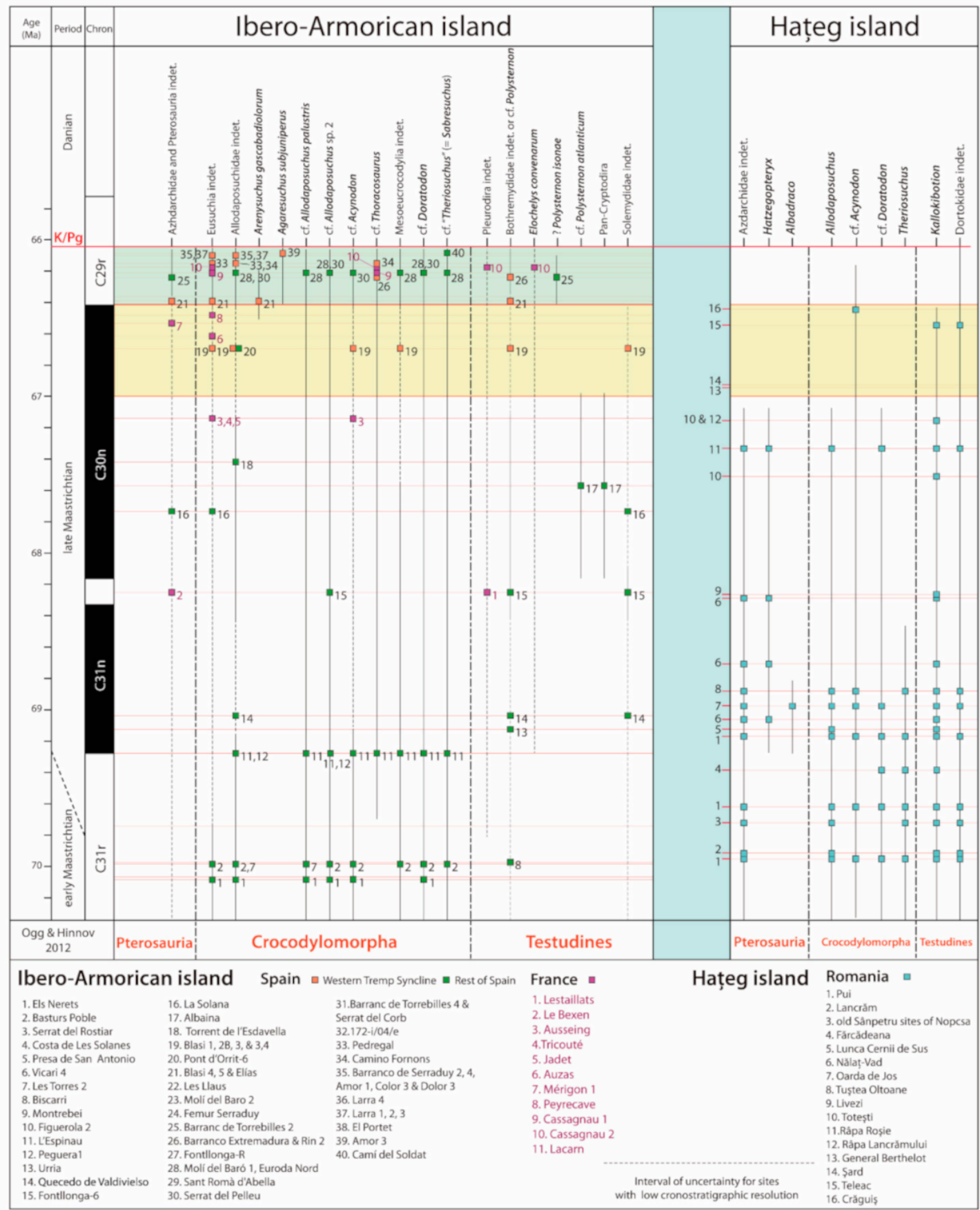

Figure 9. Pterosaur, crocodylomorph, and testudines groups and species occurrences in the Ibero-Armorican island and Haţeg island during the late Maastrichtian. Haţeg island data based on [32] with updated information. The yellow band marks the temporal interval used for comparison, whereas the green band marks the last $\approx 350$ ka of the Maastrichtian, with a record only in the Ibero-Armorican island. Magnetochronostratigraphic scale based on [153] and calibration for the K-Pg boundary based on [28].

During the late Maastrichtian, the crocodylomorphs of the Ibero-Armorican island show great abundance, with a similar number of taxa to that during the early Maastrichtian [23]. The best-represented clade is the eusuchian Allodaposuchidae, with two taxa described from the Western Tremp Syncline (Agaresuchus subjuniperus and Arenysuchus), 
and probably Allodaposuchus palustris, whose characteristic teeth have been found up to chron C29r [122,148]. In addition, Blanco et al. (2020) [122] described Allodaposuchus sp. 2 on the basis of a dentary from the Fontllonga- 6 site (C30r), which seems to be different from the allodaposuchids previously described and could represent a new taxon. Finally, there are plenty of isolated teeth of allodaposuchids $[64,121,148,159]$ that due to their conical generalist shape are difficult to ascribe to specific taxa.

Gavialoidea is represented by a skull and other associated remains from the site of Cassagnau (Haute-Garonne, southern France). These have been ascribed to Thoracosaurus neocesariensis [160]. This assignment has been debated, as the remains could belong to a new taxon [161]. In addition, more teeth referred to cf. Thoracosaurus have been found in the Spanish Pyrenees, including the record of the Western Tremp Syncline [64,122].

The diversity of hylaeochampsids, "atoposaurids", and notosuchians during the late Maastrichtian is difficult to determine, since most of their fossils are isolated teeth. There are several teeth referred to cf. Acynodon from France [162,163] and the Spanish Pyrenees, including the Western Tremp Syncline [122]. "Atoposaurids" are represented by teeth identified as cf. Theriosuchus; these are from the Spanish Pyrenees [122,148] but not the Western Tremp Syncline. "Atoposauridae" is here written in quotes, since Tennant et al. (2016) [164] have argued that some taxa assigned to this clade, such as "Theriosuchus" ibericus and "Theriosuchus" sympiestodon, belong to Paralligatoridae and have accordingly grouped these taxa under the new genus Sabresuchus. There are also some teeth from the Spanish Pyrenees identified as the notosuchian cf. Doratodon [122,148]. It should further be noted that plenty of undetermined eusuchian and crocodylomorph remains have been discovered in the French and Spanish Pyrenees (see [23] and references therein), as well as fossil tracks of crocodylomorphs [125], but due to their limited diagnostic value, it is difficult to ascertain their taxonomic status more precisely. There are also indeterminate eusuchian remains from La Solana (Valencia) [132] and Quecedo de Valdivielso (Burgos, NW Spain) $[165,166]$. Thus, Ibero-Armorican crocodylomorphs are represented during the late Maastrichtian by a minimum of eight taxa (Table 1, Figures 7 and 9).

The record of testudines during the late Maastrichtian of the Ibero-Armorican island is poorer than during the early Maastrichtian. In the Pyrenees, pleurodiran turtles are represented by the bothremydid Elochelys convenarum Laurent, Tong, Claude [167] from southern France and another bothremydid turtle from Isona. This represents the species Polysternon isonae Marmi, Luján, Riera, Gaete, Oms, Galobart [168], although Pérez-García [169] considers this a nomen dubium, lacking enough diagnostic characters for a new species, and classifies the remains as Foxemydina indet. Isolated remains of indeterminate bothremydids are also present in other sites in the Pyrenees $[128,170]$ and in the northwestern Spanish sites of Urria and Quecedo de Valdivielso (Burgos) [165,166]. In the fossil site of Albaina, there is a plate identified as cf. Polysternon atlanticum [144]. Pan-cryptodirans are represented by the remains of solemydid turtles from the Pyrenees, from the sites of Blasi and Fontllonga-6 [128,170], and from La Solana (Valencia) [132,133]. Pereda-Suberbiola et al. (2015) [144] describe a plate from a putative pan-cryptodiran that differs from solemydids. This makes a minimum of three pan-pleurodirans and two pan-cryptodirans in the Ibero-Armorican island during the late Maastrichtian (Table 1, Figures 7 and 9).

Small-sized upper Maastrichtian tetrapods from the Ibero-Armorican island are represented only by amphibians and squamates from the Spanish and French Pyrenees $[129,134,152,171]$ and from Valencia [172] (Figure 10). The first group consists of albanerpetontids, with at least one taxon present, identified in Blasi 2 as Albanerpeton aff. nexuosum [129], plus several albanerpetontid remains from the L'Espinau and Serrat del Rostiar 1 sites (Lleida, Catalonia, NE Spain) [171], Cassagnau 1 (Haute-Garonne, southern France) [134,152], and La Solana [172]. In La Solana, the presence of a salamandrid is also documented [172]. Anurans may be represented by at least four different groups with one discoglossid and one palaeobatrachid recognized at Blasi 2, L'Espinau, and Serrat del Rostiar [129,171], and an alytid and a putative pelobatid or gobiatid at L'Espinau [171]. 
It is noteworthy that there are remains of a palaeobatrachid from Valencia [172] that shows differences from the Blasi 2 taxon and could represent another taxon.

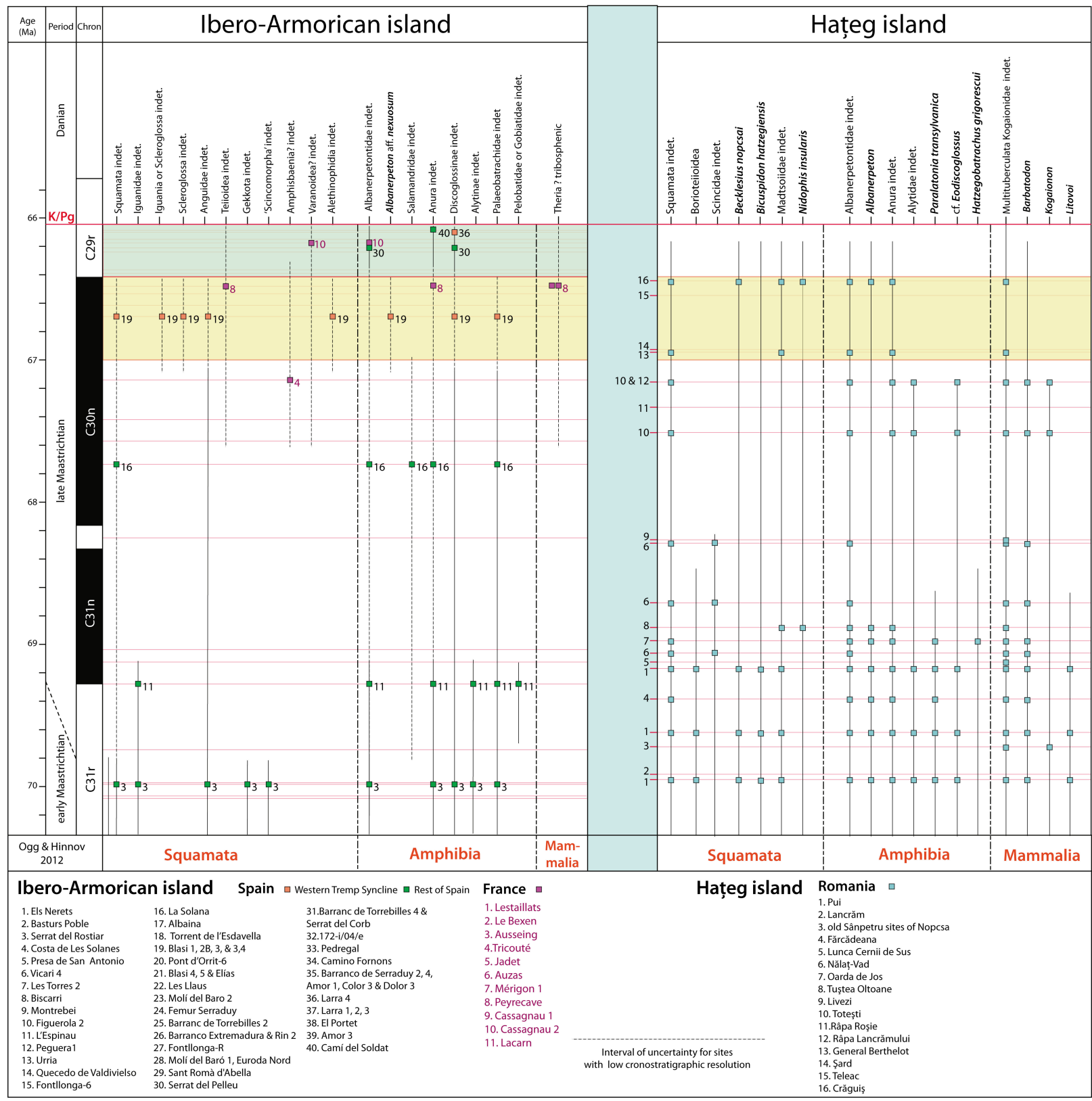

Figure 10. Squamate, amphibian and mammal groups and species occurrences in the Ibero-Armorican island and Haţeg island during the late Maastrichtian. Haţeg island data based on [32] with updated information. The yellow band marks the temporal interval used for comparison, whereas the green band marks the last $\approx 350$ ka of the Maastrichtian, with a record only in the Ibero-Armorican island. Magnetochronostratigraphic scale based on [153] and calibration for the K-Pg boundary based on [28].

Upper Maastrichtian squamates are represented by the previously described fossils from Blasi 2 [129], with two undetermined lizards, one anguid lizard, and an alethinophid snake. Additionally, in the Pyrenees, the site of Serrat del Rostiar 1 (Lleida, Catalonia) has yielded several squamate remains [171] including geckos, anguid, and "scincomorph" lizards, and an indeterminate iguanid. An indeterminate iguanid can also be found at L'Espinau. The Serrat del Rostiar 1 site is dated to within chron C31r in the early Maastrichtian, but due to its stratigraphic position, it lies very close to the boundary with 
the late Maastrichtian, so we have extended its faunal assemblage to the lower part of the late Maastrichtian (Figure 10). In the French Pyrenees, there is also evidence of a large varanoid, "scincomorph" lizards, and other indeterminate squamates [134,152]. Outside the Pyrenees, there are also undetermined squamate remains at the La Solana site [132].

It is interesting to note that during the late Maastrichtian, there is almost no evidence of mammals in the Spanish record of the Ibero-Armorican island, despite the fact that their presence is documented during the early Maastrichtian [173-175] and the earliest Paleocene $[176,177]$. The only evidence of mammals during the late Maastrichtian is some tribosphenic teeth from the Peyrecave site, in the Petites Pyrénées (Haute-Garonne, southern France). These would have belonged to a therian mammal [152,178].

\section{Discussion}

\subsection{Comparison with the Upper Maastrichtian Vertebrate Assemblage from the Hateg Island}

To assess the composition of the dinosaur communities of the European Archipelago at the end of the Cretaceous and thus how they faced the K-Pg extinction event, we performed a faunal comparison between the inferred communities of Ibero-Armorican tetrapods and those of Haţeg island, which is another European landmass with a well-known Maastrichtian tetrapod assemblage (Table 1, Figures 7 and 8). The Haţeg island encompasses part of present-day Transylvania (western Romania) [179]. During the Late Cretaceous, it was inhabited by an unusual community of vertebrates, with several groups showing dwarfism and other peculiar adaptations to insularity $[30,180]$. The upper Maastrichtian vertebrate fossils of Haţeg island are recovered mainly from the Sînpetru, Densuş-Ciula and Sebeş formations, which range from the Santonian-Campanian to the upper Maastrichtian (see [32] for a detailed chronostratigraphic framework). In the late Maastrichtian, the dinosaur assemblage consisted of rhabdodontids, hadrosauroids, titanosaurian sauropods and nodosaurid ankylosaurs, similar to the early Maastrichtian assemblages of the region; this presumably indicates that a major dinosaur turnover did not occur during the earlylate Maastrichtian transition. This represents a remarkable difference with respect to the replacement pattern observed in the Ibero-Armorican island [33]. Here, we summarize the tetrapod assemblages of Haţeg island present in tiers 3 and 4 of Csiki-Sava et al. (2016) [32], which is equivalent to the uppermost part of the lower Maastrichtian (C31r) and to the upper Maastrichtian (C31n, C30n, C30r, but not chron C29r) (Figures 8-10). In order to focus on the youngest time interval in the latest Maastrichtian in which contemporary tetrapod communities are preserved in both islands, we thus select the last 800-850 ky of the Maastrichtian, which comprises the upper part of chron C30n (yellow fringe in Figures 8-10) and the Maastrichtian part of chron C29r (green fringe in Figures 8-10). As can be observed, there are C29r vertebrate sites only in the Ibero-Armorican island (Figures 8-10).

\subsubsection{Dinosauria}

Despite both islands having very similar assemblages of dinosaurs during the early Maastrichtian, this dramatically changed in the late Maastrichtian due to the aforementioned faunal turnover on the Ibero-Armorican island. Regarding herbivorous dinosaurs, in the last $800 \mathrm{ky}$ prior to the $\mathrm{K}-\mathrm{Pg}$ event (during the upper part of chron $\mathrm{C} 30 \mathrm{n}$ and lower part of C29r), the communities of the Ibero-Armorican island were dominated by lambeosaurine hadrosaurids and titanosaurian sauropods (Table 1, Figures 7 and 8). The lambeosaurines were represented by at least four medium-sized taxa (Arenysaurus, Blasisaurus, Canardia, and Pararhabdodon), which was probably a small-sized hadrosaurid that had undergone insular dwarfism [79], and a non-hadrosaurid hadrosauroid [75]. Titanosaurs have not yet been documented in chron C30n, but they are present in C29r (Figure 8), and it is reasonable to assume that those forms present in C29r would be present in the upper part of C30n. These correspond to a large and a small-medium form [71]. In Haţeg island, by contrast, the herbivorous communities show a higher clade diversity, with rhabdodontids, hadrosauroids, nodosaurian ankylosaurs, and titanosaurs. 
The small-sized rhabdodontids were represented by two species of the genus Zalmoxes, $Z$. robustus and Z. shqiperorum [32,181,182], although the latter seems not to have reached the upper part of chron C30n (Figure 8). Hadrosauroids are represented only by the smallsized non-hadrosaurid hadrosauroid Telmatosaurus [32,183]. However, the latter could be a wastebasket taxon, and hadrosauroid diversity in the latest Maastrichtian could be higher [184]. Ankylosaurs also reached the latest Maastrichtian, although only isolated teeth and fragmentary fossils have been found [32,185-187]. However, the holotype of Struthiosaurus transylvanicus [188] might be situated in the basal part of the upper Maastrichtian (tier 3, [32]). Titanosaurs are represented by dwarf and medium-sized forms, which cohabited the island during the late Maastrichtian [189-192], although their record is absent in the lower part of C29r. At least three taxa are recognized, including Paludititan and Magyarosaurus (Table 1, Figure 8), but most of the recovered material is indeterminate and is in review [193], so the diversity of sauropods remains uncertain [32].

These differences between the two islands are clearly caused by the reorganization of the ecosystems after the arrival of lambeosaurines and new titanosaur faunas on the IberoArmorican island $[33,34]$. This group of hadrosaurids arrived on the island around the midpart of chron C31r, in the late early Maastrichtian [33]. This arrival apparently occurred in several waves, but it was all of Asian origin [80,83,84], and it represented a complete shift in the herbivorous dinosaur assemblages of the island. Hadrosaurids have been recognized as very efficient plant-eaters mainly on account of the advantages of their dental battery and feeding strategies [194-196]. Although they coexisted for some time with rhabdodontids and ankylosaurs, rhabdodontids seem to have been unable to compete and did not reach the upper part of the late Maastrichtian, disappearing from the island around the $\mathrm{C} 31 \mathrm{r}-\mathrm{C} 31 \mathrm{n}$ boundary, followed by the nodosaurid ankylosaurians in chron C30n [33] (Figure 8). By contrast, it seems that lambeosaurine hadrosaurids did not reach Haţeg island, and the Haţeg herbivorous assemblage remained stable until the K-Pg boundary. Consequently, in Haţeg island, there is no evidence of herbivore turnover due to ecosystem reorganization after the arrival of newcomers.

As regards non-avian theropods, the fossil record in both islands is composed mainly of isolated teeth, making it difficult to assess their diversity. Both islands were inhabited by several taxa of small to medium-sized maniraptoran theropods: at least three in the IberoArmorican island (Richardoestesia, Paronychodon, and a dromaeosaurid morphotype) and (historically) at least five morphotypes in Haţeg, including Richardoestesia, Paronychodon, Euronychodon, a "troodontid", and a "velociraptorine dromaeosaurid" [32,185,197] (Table 1; Figure 8). However, new research simplifies the teeth from Haţeg to within three morphospaces: Dromaeosauridae, Richardoestesia and Euronychodon [198]. The recent discovery of the troodontid Tamarro in the Ibero-Armorican island [149] represents the fourth maniraptoran theropod of the island and the first not described based on isolated teeth. It implies that troodontids were then present in both islands. However, significant differences between the islands exist regarding the medium to big-sized theropods. In the IberoArmorican island, there was at least one abelisaurid (cf. Arcovenator) during chron C30n, which would be the main predator. In the Haţeg island, there is no record of this kind of theropod, nor of any kind of medium to big-sized theropod (Figure 8). Nor is there any evidence of the enigmatic theropods Balaur [199,200] and Elopteryx [32] in the latest Maastrichtian of Haţeg island, although they are present in the lower part of the upper Maastrichtian (Figure 8). Finally, some small teeth have been found in the Ibero-Armorican island in the upper part of chron C30n; these have been referred to indeterminate small coelurosaurians (Figure 8).

Avialae are not recorded during C30n in either of the two islands (Figure 8), but in the Ibero-Armorican island, a putative enantiornithine [152] and a large ornithuromorph [110] are present during chron C29r, so their presence could be inferred in the upper part of chron C30n. In Hațeg island, enantiornithine birds [201] and gargantuaviids [202] have been recognized, but just in the lower part of the upper Maastrichtian (C31n-C30r; Figure 8). 
These faunal differences between the islands indicate that the Ibero-Armorican landmass, despite its insular condition, allowed the dispersal of faunas at some points in time. This is supported by the presence of 'Ibero-Armorican' groups outside the island (arenysaurins and titanosaurs in Africa; $[84,203]$ ) and by the arrival of Gondwanan theropods (abelisaurids; [204]) or Laurasian hadrosaurids (lambeosaurines; [139]). By contrast, the immigrants arriving at Haţeg island at the Campanian-Maastrichtian boundary did not include Asian lambeosaurines but distinct velociraptorines and possibly alvarezsaurids [30] that probably followed different migratory routes. The arrival of such newcomers seems not to have significantly altered the evolution of its "primitive" dinosaur faunas or their ecological roles, and some of them became smaller in size as a consequence of "insular dwarfism" ([180]) whereas others showed peculiar ecological adaptations (e.g., aberrant theropods [200]).

\subsubsection{Pterosauria}

Pterosaurs are represented by large azhdarchids during the late Maastrichtian of both islands, although the record in Ibero-Armorica is scarcer and more fragmentary [114,154,157]. In Haţeg, during the late Maastrichtian, at least two different taxa of giant azhdarchids (Hatzegopteryx [191,205,206] and Albadraco [207]) (Table 1) coexisted, despite there being no record of them in the upper part of C30n and C29r. However, it seems plausible that they were present since there are remains of indeterminate azhdarchids in that interval (Figure 9). It has been suggested that in Hateg island, these giant azhdarchids would have occupied the role of large predators due to the absence of large theropods in the island [206]. Their ecological role in the Ibero-Armorican island is more difficult to determine, since there were medium-large theropods (abelisaurids) dwelling on the island.

\subsubsection{Crocodylomorpha}

The main clades of Crocodylomorpha present in the latest Cretaceous of Europe already inhabited the continent millions of years before the extinction at the K-Pg boundary. The most common clade is Allodaposuchidae, whose earliest record is from the Santonian of Hungary [208]. Subsequently, these basal eusuchians became the dominant crocodylomorphs during the Campanian and Maastrichtian of Europe. During the late Maastrichtian of the Ibero-Armorican island, indeterminate allodaposuchids (mostly isolated teeth) are present in most stratigraphic levels up to the uppermost part of the Maastrichtian part of chron C29r (Figure 9). Many of these teeth may fall within C29r and belong to Arenysuchus gascabadiolorum, Agaresuchus subjuniperus, or other unknown species, but their generalist morphology does not allow a more specific assignment. Other remains with a more peculiar morphology may belong to the lower Maastrichtian species Al. palustris, and thus, its record would cover almost the entire Maastrichtian [122]. In addition, remains very similar to a specimen that Blanco et al. (2020) [122] assigned to Allodaposuchus sp. 2 are present throughout the upper Maastrichtian. Therefore, during the late Maastrichtian and up to the K-Pg boundary, there was a great abundance of defined species of allodaposuchids in the Ibero-Armorican island, with at least three species and a fourth possible new species. This contrasts with the allodaposuchid situation observed in Hateg island during this time interval, where only remains assigned to Allodaposuchus sp. have been described (e.g., [32]). Whether these remains belong to the Romanian species $A l$. precedens or to other taxa is difficult to establish, since most occurrences are based on undiagnostic postcranial material or isolated teeth with generalist morphologies typical of several contemporary European taxa such as Arenysuchus and Agaresuchus. Another difference between the allodaposuchids of the two islands is that the last record in Haţeg occurs in the middle part of chron C30n. Whether their absence during the last million years before the K-Pg boundaryis real or due to some kind of bias cannot be determined in the present work. However, it should be noted that in most Maastrichtian microvertebrate sites in Europe, the conical teeth of Allodaposuchidae are among the most common remains, appearing in a wide variety 
of sedimentary environments [122]. Consequently, the hypothesis that the clade truly disappeared at the end of the Maastrichtian, and that this disappearance is not merely an artifact of biases, must be considered.

Another common clade of basal eusuchians during the late Maastrichtian of Europe is Hylaeochampsidae, specifically the genus Acynodon. This genus is known from the Campanian to the late Maastrichtian of Europe (e.g., [23]). Most of the late Maastrichtian remains assigned to this taxon are isolated teeth with a peculiar button-like (molariform, tribodont) morphology associated with durophagy. Although this dental morphology is present in several lineages among Crocodylomorpha (e.g., Bernissartia), so far, the only European Late Cretaceous taxon with this morphology is Acynodon. For this reason, these teeth are usually assigned to cf. Acynodon. In contrast to the allodaposuchids, there is a similar record of the clade on both islands, covering most of the late Maastrichtian. The last record of cf. Acynodon (and the last record of Crocodylomorpha in Haţeg) occurs at the end of chron C30n. This last appearance is based on an isolated blunt tooth recovered in Crăguiş, which is a very rich area for microvertebrates ([32]). However, the presence of Acynodon and other vertebrates in Haţeg island during chron C29r cannot be ascertained, as there is no sedimentary record for this period [32] (Figure 9).

During the late Maastrichtian, the only clade whose presence is recorded in the IberoArmorican island but not in Haţeg is Crocodylia, with a single representative, the genus Thoracosaurus. The presence of this genus is based on an almost complete skull, teeth, osteoderms, and vertebrae recovered within chron C29r of Cassagnau 1 and 2 (HauteGaronne, France) $[134,160]$. In addition, isolated slender conical teeth tentatively assigned to cf. Thoracosaurus have been recovered from deposits of the lower and upper part of the upper Maastrichtian of the Tremp Basin in Spain [122]. The scarce representatives of the crown group Crocodylia during the Late Cretaceous of Europe, and the fact that most of the Thoracosaurus remains have been recovered in marine and coastal paleoenvironments (e.g., $[23,122,160,161])$, could explain the scarcity of remains in the continental deposits of the Ibero-Armorican island and their absence in Haţeg. Interestingly, Thoracosaurus is the only European crocodylomorph that has been recovered below and above the K-Pg boundary.

Only two clades of non-eusuchian crocodylomorphs have been found in the Maastrichtian of Europe, "Atoposauridae" and Notosuchia. Most of the "atoposaurid" record in the Upper Cretaceous of Europe is based on isolated teeth similar to those present in Sabresuchus (=Theriosuchus) sympiestodon [209], whose type material was found in the lower Maastrichtian of the Densuş-Ciula Fm but also reported from upper Maastrichtian sites on Haţeg island, although it does not reach the upper part of the upper Maastrichtian $[32,210]$ (Figure 9). Remains assigned to this taxon are also present throughout the upper Maastrichtian of the Ibero-Armorican island $[23,148]$. As regards Notosuchia, many ziphodont teeth similar to Doratodon carcharidens from the Campanian of Austria and the Santonian of Hungary [211] have been found in the Maastrichtian of the Ibero-Armorican island and Haţeg (e.g., [32,122]). As happens with other crocodylomorphs, there is a record of both clades throughout the upper Maastrichtian of the Ibero-Armorican island, but they disappear at the top of chron C30n in Haţeg.

As we have already pointed out, the most striking difference between the Crocodylomorpha record of the Ibero-Armorican island and Haţeg is the almost complete absence of crocodylomorphs from the top of chron C30n in Hațeg island. Several factors could explain this, such as geological and sampling biases. However, the abundance of microfossil sites from the top of chron C30n in Haţeg, together with the fact that crocodylomorphs are usually among the most abundant remains found in this kind of site [32], make it difficult to justify their absence by biases alone. Further studies are needed to clarify this question.

Therefore, the crocodylomorph fossil assemblage of Europe during the Maastrichtian is mostly composed of endemic European taxa such as Allodaposuchidae, Hylaeochampsidae, and Sabresuchus. This would imply sporadic connections and faunal exchanges between the two islands, probably via the Adriatic-Australpine domain [116], and subse- 
quent isolation processes that allowed endemism and differentiation at species and even the genus level. Isolated cases of intercontinental faunal exchange are explained by the presence of taxa with Gondwanan affinities such as Notosuchia (Doratodon) in the Maastrichtian of both islands, and the presence of taxa with North American affinities such as Crocodylia (Thoracosaurus) in the late Maastrichtian of the Ibero-Armorican island. The presence of Doratodon is explained by several episodic Cretaceous faunal and geographical links between Africa and Europe [211], such as a Turonian-Coniacian immigration wave that connected eastern Europe and northern Africa [30,212]. The presence of Thoracosaurus, a common taxon in North America, could be explained by the more aquatic and cosmopolitan nature of this taxon, which was able to move great distances across the ocean or, for example, via the Thulean Land Bridge [115].

\subsubsection{Testudines}

The record of turtles in the two islands shows a certain contrast. The diversity of testudines in the Ibero-Armorican island appears to be greater than in Haţeg, with three freshwater taxa of bothremydid pleurodirans (Elochelys, Polysternon isonae? and Polysternon atlanticum) reaching the C29r (Figure 9), and at least one taxon of a solemydid cryptodiran and an indeterminate pan-cryptodiran. By contrast, in Haţeg, there are no cryptodiran turtles.

Haţeg turtles are represented only by two main groups that span the whole Maastrichtian: the basal turtle (stem Testudines) Kallokibotion, and the dortokids, which are stem pleurodirans and are present during the upper part of chron C30r [32,213,214] (Table 1, Figure 9).

\subsubsection{Amphibia and Squamata}

The upper Maastrichtian assemblages of amphibians in the Ibero-Armorican island (upper part of chron C30n) consist of albanerpetontids, discoglossid anurans, palaeobatrachids, and probably salamandrids (Figure 10). In Haţeg island, the assemblages are dominated by albanerpetontids and alytid anurans $[32,215]$, the latter represented by two taxa (Paralatonia transylvanica and cf. Eodiscoglossus). However, there is no direct evidence of these two taxa in the upper part of C30n (Figure 10). Moreover, the presence of the bombinatorid Hatzegobatrachus is documented in the lower part of the upper Maastrichtian [215]. The absence of palaeobatrachids in Haţeg island is also noteworthy.

The squamate assemblages of both islands are diverse and have some groups in common (anguimorph and "scincomorph" lizards, teiioids) but also show some differences (Table 1, Figure 10). In Haţeg island, there are borioteiioid lizards (Bicuspidon hatzegiensis) and paramacellodids, which are represented by Becklesius nopcsai [32,216-218]. Snakes are represented by the madtsoiid Nidophis insularis [219,220], which shows Gondwanan affinities. This clade of snakes has no record in the upper Maastrichtian deposits of the IberoArmorican island but is present in the lower Maastrichtian [30,221]. In the Ibero-Armorican island, there are certain groups that do not appear in Hațeg, such as varanoids and iguanids (Table 1, Figure 10).

\subsubsection{Mammalia}

During the late Maastrichtian, mammals were part of the communities of both islands, but there is almost no information about those of the Ibero-Armorican island, except the alleged therian teeth from Peyrecave $[152,178]$, which is situated in the upper part of the upper Maastrichtian. By contrast, mammals from Haţeg island are well known, with at least three taxa of kogaionid multituberculate mammals: Barbatodon, Kogaionon, and Litovoi [32,222-224] (Table 1) (Figures 7 and 10). Kogaionids were a group of multituberculates endemic to Haţeg island that survived up to the top of the Maastrichtian and made it to the Paleocene, diversifying and dispersing through Europe [225]. 


\subsection{Evaluation of the Tetrapod Diversity of the Ibero-Armorican Island and Its Biases}

Despite the high number of fossiliferous localities that are known in the last million years of the Cretaceous in the Tremp Basin (over 50, see Figure 2), the fossil record of tetrapods is certainly limited by a series of factors including geological history, rock outcrop area, taphonomy, and study and sampling biases [226-229], as well as uncertainties in the taxonomic identification of specimens and the dating of the fossil-bearing deposits. Such biases (resulting, for example, from variations in the fossilization potential of vertebrate remains, interruptions in deposition in continental environments, anagenetic evolutionary lineages, syn-sedimentary and post-sedimentary erosion, etc.) strongly influence the measurement of diversity (i.e., taxonomic richness over a given time period). Some of them are shared with the coeval fossil records of continental to transitional fossiliferous deposits $[230,231]$, but others are specific to the Ibero-Armorican island.

As far as geological and rock outcrop area biases are concerned, the available outcrops of the uppermost Maastrichtian beds are limited by the following factors: the geological history of the basin, the outcrop area, and the number of exposures. The relatively extensive Ibero-Armorican island has reduced potential for fossiliferous outcrops, due to its geological history. In the Pyrenean region, the Alpine orogeny has had an important impact on the availability of outcrops and localities. Thus, a significant reduction in outcrops occurred due to a series of thrusts that caused a shortening of circa $120 \mathrm{~km} \mathrm{[232].} \mathrm{Second,}$ highly erosive fluvial and glacial valleys generated during and after the last glaciation have eroded Mesozoic formations for thousands of years, further limiting potential outcrops. The number of exposures (i.e., sedimentary bedrock that is visibly exposed at the surface) is constrained by the Pyrenean climate, which favors a high level of vegetation cover. However, in general terms, the southern Pyrenean regions are less forested than the northern foothills, and this enhances the number of available exposures.

As regards taphonomic biases, it is worth mentioning that because of the fragmentary character of the fossil remains commonly found in the Lower Red Garumnian of the Tremp Basin (channel-lag bone accumulations from fluvial-deltaic channelized sandstones, modes 1 and 2 of [233]), major uncertainties exist in the taxonomy of most of the collected specimens. Consequently, their taxonomic assignment is usually to what is commonly held to be a family rank (e.g., Azhdarchidae, Bothremydidae, Titanosauridae, Rhabdodontidae, Solemydidae) or a superfamily rank (Hadrosauroidea, Varanoidea) (Figures 8-10). A similar scenario has been observed in the Haţeg Basin [32]. This reveals that our understanding of the real taxonomic diversity in both regions is preliminary, and diversity comparisons between the regions at lower taxonomic levels (genus or species level) are still not possible. Furthermore, we concur with previous authors [234,235] that the diversity of dinosaurs varies in different paleobioprovinces because of climatic, environmental, or biotic conditions that caused differences in dinosaur evolution. Therefore, endemism or variations in speciation due to the particularities of insular ecosystems are assumed.

With respect to study and sampling biases, the accessibility of sedimentary rock exposures and variations in the efforts of paleontologists in the region are the two main factors affecting the fossil record. First, the complex relief of the Western Tremp Basin reduces accessibility to some of the outcrops (Figure 3), hindering the collection of large macroremains or representative amounts of bulk rock for sieving. Sampling efforts made by paleontologists are unequal as well. Indeed, there are microvertebrate fossil assemblages present in the Maastrichtian outcrops of the Tremp Basin that have not been sampled. One exception is the great effort made by some teams in the 1990s in their pursuit of mammal microfossils [177]. This otherwise unsuccessful survey resulted in the discovery of important localities such as Blasi 2 and Fontllonga 6 [129,151]. Prospecting efforts are currently being carried out in selected localities_L'Espinau, Veracruz 1 [43,57,171]but an extensive microfossil sampling campaign is lacking. Regarding macrovertebrates, the greater amount of hadrosaur and crocodylomorph fossils-probably because their osteological remains are both more resilient and more easily identifiable compared with other vertebrate clades-produced a clear study bias in the faunal diversity of the Tremp 
Formation. These two clades of vertebrates have been the subject of further studies probably because their fossils are more informative or better preserved and thus allow greater taxonomic resolution. By contrast, other groups such as pterosaurs, turtles, sauropods, and theropods have a more fragmentary and less diagnostic fossil record that makes assessment of their abundance more difficult.

Finally, however, one of the key strengths of the fossil record in the Tremp Basin is the dating of the fossil-bearing deposits. In this context, detailed correlations of stratigraphic successions and magnetochrons coupled with accurate age constraints provided by planktic foraminifera $[56,60,64]$ provide a solid chronostratigraphic framework.

By all these reasons, interpreting if there was or not a decline in the diversity of some groups of tetrapods before the K-Pg boundary in the islands of the European archipelago is difficult. However, the discovery during the last years of new taxa whose presence was not known in the islands (e.g., the troodontid Tamarro [149], the ornituromorph from Beranuy [110], or the azhdarchid Albadraco [207]) points that the late Maastrichtian tetrapod ecosystems were in fact more diverse that what the studied fossil record had pointed up to the day. By this reason, it seems plausible to think that diversity was far from declining prior to the extinction, but this would perhaps be a daredevil judgment, since a higher resolution of the Maastrichtian fossil record (in number of specimens and age constrains) is needed in the Maastrichtian to observe differences and clear trends in the evolution of diversity.

\section{Conclusions}

The vertebrate record of the Western Tremp Syncline comprises some of the youngest sedimentary deposits with vertebrate fossils in the late Maastrichtian of Europe, with a continuous succession from the upper part of chron C30r to chron C29r ( $\approx 67-66.052 \mathrm{Ma})$. Among the upper Maastrichtian outcrops of the Tremp and Arén Sandstone formations in this area, more than 50 fossil sites have been recognized. Fossils have been recovered belonging to hadrosauroid ornithopods, including the holotypes of Arenysaurus and Blasisaurus, titanosaurian sauropods, abelisaurid and maniraptoran theropods, a large avialan ornithuromorph, pterosaurs, non-eusuchian and eusuchian crocodylomorphs, including the holotypes Arenysuchus and Agaresuchus subjuniperus, pleurodiran and cryptodiran turtles, squamates, and amphibians. This record is augmented by a relatively diverse oological record, albeit one in need of further study, and ichnites of both dinosaurs (Hadrosauropodus) and crocodylomorphs (Characichnos and cf. Crocodylopodus).

A first attempt at comparing Late Cretaceous European regions indicates that the IberoArmorican island and Haţeg island show diverse and thriving communities of vertebrates during the late Maastrichtian, with certain differences in the faunas probably caused by their different paleobiogeographic evolution. Despite these differences, it seems that both European islands flourished during the late Maastrichtian. The rich record of the IberoArmorican island and its chronostratigraphic framework indicate that its tetrapod assemblages were thriving just a few hundred thousand years before the K-Pg extinction, and some groups even just tens of thousands of years before.

Despite its small size and relatively inaccessible outcrops, the Western Tremp Syncline is a privileged area when it comes to studying the last Mesozoic ecological communities of tetrapods in Europe, and it is key to understanding how they were affected by the K-Pg extinction event. Further research in this area would help to unveil missing taxa and shed light on these communities and the environment in which they lived.

Supplementary Materials: The following are available online at https:/ / www.mdpi.com/article/10 .3390/geosciences11040162/s1, Table S1: Arén and Tremp Fm Aragonese sites.

Author Contributions: Conceptualization, M.P.-P.; writing-original draft preparation, M.P.-P.; writing-review and editing, P.C.-C., M.M.-A., E.P.-P., D.C., B.V., J.M.G., B.B., J.I.C. supervision, E.P.-P., B.B., J.I.C. All authors have read and agreed to the published version of the manuscript. 
Funding: This research was funded by the Spanish Ministry of Science and Innovation, the European Regional Development Fund, the Government of Aragón (Grupo Aragosaurus: Recursos geológicos y Paleoambientes), project CGL2017-85038-P; by the Fundação para a Ciência e a Tecnologia, project PTDC/CTA-PAL/31656/2017 and GeoBioTec, project (UIDB/04035/2020). M.P.-P. is supported by a Ph.D grant from the Spanish Ministry of Education, Culture and Sport (Grant Number FPU 16/03064). M.M.-A. and E.P.-P. are supported by postdoctoral grants funded by the Fundação para a Ciência e a Tecnologia, Portugal (Grant numbers SFRH/BPD/113130/2015, SFRH/BPD/116759/2016, PTDC/CTA-PAL/31656/2017). D.C. is supported by the Beatriu de Pinós postdoctoral programme (BP2017-00195) of the Government of Catalonia's Secretariat for Universities and Research of the Ministry of Economy and Knowledge. B.V. is part of the consolidated research group 2017 SGR 01666 of the Agència de Gestió i Ajuts Universitaris i de Recerca (AGAUR). Additional support was also provided by the CERCA Programme of the Generalitat de Catalunya.

Acknowledgments: We would like to acknowledge Isabel Pérez for the photographs of MPZ 2021/1, and Diego Torromé for the photograph of the Serraduy outcrops. We would also like to thank the Servicio General de Apoyo a la Investigación-SAI, Universidad de Zaragoza for the SEM photographs. We would like to thank the valuable comments of two anonymous reviewers, which have contributed substantially to the improvement of this work. Rupert Glasgow reviewed the text in English.

Conflicts of Interest: The authors declare no conflict of interest. The funders had no role in the design of the study; in the collection, analyses, or interpretation of data; in the writing of the manuscript, or in the decision to publish the results.

\section{References}

1. Alvarez, L.W.; Alvarez, W.; Asaro, F.; Michel, H.V. Extraterrestrial cause for the cretaceous-tertiary extinction. Science 1980, 208, 1095-1108. [CrossRef] [PubMed]

2. Miller, K.G.; Kominz, M.A.; Browning, J.V.; Wright, J.D.; Mountain, G.S.; Katz, M.E.; Sugarman, P.J.; Cramer, B.S.; Christie-Blick, N.; Peka, S.F. The Phanerozoic Record of Global Sea-Level Change. Science 2005, 310, 1293-1298. [CrossRef] [PubMed]

3. Li, L.; Keller, G. Maastrichtian climate, productivity and faunal turnovers in planktic foraminifera in South Atlantic DSDP sites 525A and 21. Mar. Micropaleontol. 1998, 33, 55-86. [CrossRef]

4. Barnet, J.S.K.; Littler, K.; Kroon, D.; Leng, M.J.; Westerhold, T.; Röhl, U.; Zachos, J.C. A new high-resolution chronology for the late Maastrichtian warming event: Establishing robust temporal links with the onset of Deccan volcanism. Geology 2018, 46, 147-150. [CrossRef]

5. Courtillot, V.; Féraud, G.; Maluski, H.; Vandamme, D.; Moreau, M.G.; Besse, J. Deccan flood basalts and the Cretaceous/Tertiary boundary. Nature 1988, 333, 843-846. [CrossRef]

6. Courtillot, V.E.; Renne, P.R. On the ages of flood basalt events. Comptes Rendus Geosci. 2003, 335, 113-140. [CrossRef]

7. Tobin, T.S.; Ward, P.D.; Steig, E.J.; Olivero, E.B.; Hilburn, I.A.; Mitchell, R.N.; Diamond, M.R.; Raub, T.D.; Kirschvink, J.L. Extinction patterns, $\delta 18 \mathrm{O}$ trends, and magnetostratigraphy from a southern high-latitude Cretaceous-Paleogene section: Links with Deccan volcanism. Palaeogeogr. Palaeoclimatol. Palaeoecol. 2012, 350-352, 180-188. [CrossRef]

8. Schoene, B.; Eddy, M.P.; Samperton, K.M.; Keller, C.B.; Keller, G.; Adatte, T.; Khadri, S.F.R. U-Pb constraints on pulsed eruption of the Deccan Traps across the end-Cretaceous mass extinction. Science 2019, 363, 862-866. [CrossRef]

9. Hildebrand, A.R.; Penfield, G.T.; Kring, D.A.; Pilkington, M.; Camargo, Z.A.; Jacobsen, S.B.; Boynton, W.V. Chicxulub Crater: A possible Cretaceous/Tertiary boundary impact crater on the Yucatán Peninsula, Mexico. Geology 1991, 19, 867. [CrossRef]

10. Renne, P.R.; Arenillas, I.; Arz, J.A.; Vajda, V.; Gilabert, V.; Bermúdez, H.D. Multi-proxy record of the Chicxulub impact at the Cretaceous-Paleogene boundary from Gorgonilla Island, Colombia. Geology 2018, 46, 547-550. [CrossRef]

11. Maruoka, T. Mass Extinction at the cretaceous-paleogene (K-Pg) boundary. In Astrobiology; Springer: Singapore, 2019; pp. 303-320.

12. Lyons, S.L.; Karp, A.T.; Bralower, T.J.; Grice, K.; Schaefer, B.; Gulick, S.P.S.; Morgan, J.V.; Freeman, K.H. Organic matter from the Chicxulub crater exacerbated the K-Pg impact winter. Proc. Natl. Acad. Sci. USA 2020, 117, 25327-25334. [CrossRef]

13. Schulte, P.; Alegret, L.; Arenillas, I.; Arz, J.A.; Barton, P.J.; Bown, P.R.; Bralower, T.J.; Christeson, G.L.; Claeys, P.; Cockell, C.S.; et al. The chicxulub asteroid impact and mass extinction at the cretaceous-paleogene boundary. Science 2010, 327, 1214-1218. [CrossRef]

14. Witts, J.D.; Whittle, R.J.; Wignall, P.B.; Crame, J.A.; Francis, J.E.; Newton, R.J.; Bowman, V.C. Macrofossil evidence for a rapid and severe Cretaceous-Paleogene mass extinction in Antarctica. Nat. Commun. 2016, 7, 11738. [CrossRef]

15. Chiarenza, A.A.; Farnsworth, A.; Mannion, P.D.; Lunt, D.J.; Valdes, P.J.; Morgan, J.V.; Allison, P.A. Asteroid impact, not volcanism, caused the end-Cretaceous dinosaur extinction. Proc. Natl. Acad. Sci. USA 2020, 117, 17084-17093. [CrossRef]

16. Dzombak, R.M.; Sheldon, N.D.; Mohabey, D.M.; Samant, B. Stable climate in India during Deccan volcanism suggests limited influence on K-Pg extinction. Gondwana Res. 2020, 85, 19-31. [CrossRef]

17. Raup, D.M.; Sepkoski, J.J. Mass extinctions in the marine fossil record. Science 1982, 215, 1501-1503. [CrossRef]

18. Jablonski, D. Extinctions in the fossil record. Philos. Trans. R. Soc. London Ser. B Biol. Sci. 1994, 344, 11-17. [CrossRef]

19. Bardet, N. Extinction events among Mesozoic marine reptiles. Hist. Biol. 1994, 7, 313-324. [CrossRef] 
20. Longrich, N.R.; Tokaryk, T.; Field, D.J. Mass extinction of birds at the Cretaceous-Paleogene (K-Pg) boundary. Proc. Natl. Acad. Sci. USA 2011, 108, 15253-15257. [CrossRef]

21. Longrich, N.R.; Martill, D.M.; Andres, B. Late Maastrichtian pterosaurs from North Africa and mass extinction of Pterosauria at the Cretaceous-Paleogene boundary. PLOS Biol. 2018, 16, e2001663. [CrossRef]

22. Brusatte, S.L.; Butler, R.J.; Barrett, P.M.; Carrano, M.T.; Evans, D.C.; Lloyd, G.T.; Mannion, P.D.; Norell, M.A.; Peppe, D.J.; Upchurch, P.; et al. The extinction of the dinosaurs. Biol. Rev. 2015, 90, 628-642. [CrossRef]

23. Puértolas-Pascual, E.; Blanco, A.; Brochu, C.A.; Canudo, J.I. Review of the late cretaceous-early paleogene crocodylomorphs of Europe: Extinction patterns across the K-PG boundary. Cretac. Res. 2016, 57, 565-590. [CrossRef]

24. Pearson, D.A.; Schaefer, T.; Johnson, K.R.; Nichols, D.J.; Hunter, J.P. Vertebrate biostratigraphy of the Hell Creek Formation in southwestern North Dakota and northwestern South Dakota. Spec. Pap. Geol. Soc. Am. 2002, 361, 145-167. [CrossRef]

25. Lyson, T.R.; Longrich, N.R. Spatial niche partitioning in dinosaurs from the latest Cretaceous (Maastrichtian) of North America. Proc. R. Soc. B Biol. Sci. 2011, 278, 1158-1164. [CrossRef]

26. Johnson, K.R.; Nichols, D.J.; Hartman, J.H. Hell Creek Formation: A 2001 synthesis. Geol. Soc. Am. Spec. Pap. 2002, 361, 503-510.

27. LeCain, R.; Clyde, W.C.; Wilson, G.P.; Riedel, J. Magnetostratigraphy of the Hell Creek and lower Fort Union Formations in northeastern Montana. In Through the End of the Cretaceous in the Type Locality of the Hell Creek Formation in Montana and Adjacent Areas; Geological Society of America: Boulder, CO, USA, 2014.

28. Sprain, C.J.; Renne, P.R.; Clemens, W.A.; Wilson, G.P. Calibration of chron C29r: New high-precision geochronologic and paleomagnetic constraints from the Hell Creek region, Montana. GSA Bull. 2018, 130, 1615-1644. [CrossRef]

29. Fowler, D. The Hell Creek Formation, Montana: A stratigraphic review and revision based on a sequence stratigraphic approach. Geosciences 2020, 10, 435. [CrossRef]

30. Csiki-Sava, Z.; Buffetaut, E.; Ôsi, A.; Pereda-Suberbiola, X.; Brusatte, S.L. Island life in the Cretaceous-Faunal composition, biogeography, evolution, and extinction of land-living vertebrates on the Late Cretaceous European archipelago. Zookeys 2015, 469, 1-161. [CrossRef] [PubMed]

31. Canudo, J.I.; Oms, O.; Vila, B.; Galobart, À.; Fondevilla, V.; Puértolas-Pascual, E.; Sellés, A.G.; Cruzado-Caballero, P.; DinarèsTurell, J.; Vicens, E.; et al. The upper Maastrichtian dinosaur fossil record from the southern Pyrenees and its contribution to the topic of the Cretaceous-Palaeogene mass extinction event. Cretac. Res. 2016, 57, 540-551. [CrossRef]

32. Csiki-Sava, Z.; Vremir, M.; Vasile, Ş.; Brusatte, S.L.; Dyke, G.; Naish, D.; Norell, M.A.; Totoianu, R. The east side story-The Transylvanian latest Cretaceous continental vertebrate record and its implications for understanding Cretaceous-Paleogene boundary events. Cretac. Res. 2016, 57, 662-698. [CrossRef]

33. Fondevilla, V.; Riera, V.; Vila, B.; Sellés, A.G.; Dinarès-Turell, J.; Vicens, E.; Gaete, R.; Oms, O. Galobart Chronostratigraphic synthesis of the latest Cretaceous dinosaur turnover in south-western Europe. Earth Sci. Rev. 2019, 191, 168-189. [CrossRef]

34. Vila, B.; Sellés, A.G.; Brusatte, S.L. Diversity and faunal changes in the latest Cretaceous dinosaur communities of southwestern Europe. Cretac. Res. 2016, 57, 552-564. [CrossRef]

35. Gómez-Gras, D.; Roigé, M.; Fondevilla, V.; Oms, O.; Boya, S.; Remacha, E. Provenance constraints on the Tremp Formation paleogeography (southern Pyrenees): Ebro Massif VS Pyrenees sources. Cretac. Res. 2016, 57, 414-427. [CrossRef]

36. Puigdefàbregas, C.; Muñoz, J.A.; Marzo, M. Thrust Belt Development in the Eastern Pyrenees and Related Depositional Sequences in the Southern Foreland Basin; Wiley: Hoboken, NJ, USA, 1986.

37. Muñoz, J.A. Evolution of a continental collision belt: ECORS-Pyrenees crustal balanced cross-section. In Thrust Tectonics; Springer: Dordrecht, The Netherlands, 1992; pp. 235-246.

38. Teixell, A. Crustal structure and orogenic material budget in the west central Pyrenees. Tectonics 1998, 17, 395-406. [CrossRef]

39. Teixell, A. Estructura de los Pirineos: Generalidades. In Geología de España; SGE-IGME: Madrid, Spain, 2004 ; pp. $321-323$.

40. Costa, E.; Garcés, M.; López-Blanco, M.; Beamud, E.; Gómez-Paccard, M.; Larrasoaña, J.C. Closing and continentalization of the South Pyrenean foreland basin (NE Spain): Magnetochronological constraints. Basin Res. 2009, 36, 349-364. [CrossRef]

41. Ardévol, L.; Klimowitz, J.; Malagón, J.; Nagtegaal, P.J.C. Depositional sequence response to foreland deformation in the upper Cretaceous of the Southern Pyrenees, Spain. Am. Assoc. Pet. Geol. Bull. 2000, 84, 566-588. [CrossRef]

42. Oms, O.; Fondevilla, V.; Riera, V.; Marmi, J.; Vicens, E.; Estrada, R.; Vila, B. Transitional environments of the lower Maastrichtian South-Pyrenean Basin (Catalonia, Spain): The Fumanya Member tidal flat. Cretac. Res. 2016, 57, 428-442. [CrossRef]

43. Rosell, J.; Linares, R.; Llompart, C. El “garumniense” prepirenaico. Rev. Soc. Geol. España 2001, 14, 47-56.

44. Mey, P.H.W.; Nagtegaal, P.J.C.; Roberti, K.J.; Hartevelt, J.J.A. Lithostratigraphic subdivision of Post-Hercynian deposits in the South-Central Pyrenees, Spain. Leidse Geol. Meded. 1968, 41, 221-228.

45. Nagtegaal, P.J.C.; Van Vliet, A.; Brouwer, J. Syntectonic coastal offlap and concurrent turbidite deposition: The Upper Cretaceous Aren sandstone in the South-Central Pyrenees, Spain. Sediment. Geol. 1983, 34, 185-218. [CrossRef]

46. Mutti, E.; Sgavetti, M. Sequence stratigraphy of the Upper Cretaceous Aren strata in the Aren-Orcau region, south-central Pyrenees, Spain: Distinction between eustatically and tectonically controlled depositional sequences. Ann. Univ. Ferrara 1987, 1, $1-22$.

47. Nagtegaal, P.J.C. Depositional history and clay minerals of the Upper Cretaceous basin in the south-central Pyrenees, Spain. Leidse Geol. Meded. 1972, 47, 251-275.

48. Mutti, E.; Rosell, J.; Ghibaudo, G.; Obrador, A. The Upper Cretaceous Aren Sandstone in its type-area. In Proceedings of the 9th International Congress International Association of Sedimentologists, Nice, France, 1 January-30 November 1975 ; pp. 7-15. 
49. Díaz-Molina, M.; Kälin, O.; Benito, M.I.; Lopez-Martinez, N.; Vicens, E. Depositional setting and early diagenesis of the dinosaur eggshell-bearing Aren Fm at Bastus, Late Campanian, south-central Pyrenees. Sediment. Geol. 2007, 199, 205-221. [CrossRef]

50. Leymerie, A. Présence de garumnien en Espagne. Bulletin de la Sociéte Géologique de France. Bull. Soc. Géol. Fr. 1868, 25, 906-911.

51. Cuevas, J.L. Estratigrafía del «Garumniense» de la Conca de Tremp. Prepirineo de Lérida. Acta Geológica Hispánica 1992, 27, 95-108.

52. Pujalte, V.; Schmitz, B. The stratigraphy of the Tremp Group revisited (Garumnian, Tremp-Graus basin, South Pyrenees). Geogaceta 2005, 38, 79-82.

53. Díaz-Molina, M. Sedimentación sintectónica asociada a una subida relativa del nivel del mar durante el Cretácico Superior (Fm. Tremp, provincia de Lérida). Estud. Geol. Núm. Extraordin. Galve Tremp. 1987, 43, 69-93.

54. Eichenseer, H. Facies Geology of Late Maastrichtian to Early Eocene Coastal and Shallow Marine Sediments (Tremp-Graus Basin, Northeastern Spain); Universität Tübingen: Tübingen, Germany, 1988.

55. Riera, V.; Oms, O.; Gaete, R.; Galobart, À. The end-Cretaceous dinosaur succession in Europe: The Tremp Basin record (Spain). Palaeogeogr. Palaeoclimatol. Palaeoecol. 2009, 283, 160-171. [CrossRef]

56. Díez-Canseco, D.; Arz, J.A.; Benito, M.I.; Díaz-Molina, M.; Arenillas, I. Tidal influence in redbeds: A palaeoenvironmental and biochronostratigraphic reconstruction of the Lower Tremp Formation (South-Central Pyrenees, Spain) around the Cretaceous/Paleogene boundary. Sediment. Geol. 2014, 312, 31-49. [CrossRef]

57. Blanco, A.; Szabó, M.; Blanco-Lapaz, À.; Marmi, J. Late Cretaceous (Maastrichtian) Chondrichthyes and Osteichthyes from northeastern Iberia. Palaeogeogr. Palaeoclimatol. Palaeoecol. 2017, 465, 278-294. [CrossRef]

58. Ghinassi, M.; Oms, O.; Cosma, M.; Finotello, A.; Munari, G. Reading tidal processes where their signature is cryptic: The Maastrichtian meandering channel deposits of the Tremp Formation (Southern Pyrenees, Spain). Sedimentology 2020. [CrossRef]

59. Villalba-Breva, S.; Martín-Closas, C. Upper Cretaceous paleogeography of the Central Southern Pyrenean Basins (Catalonia, Spain) from microfacies analysis and charophyte biostratigraphy. Facies 2013, 59, 319-345. [CrossRef]

60. Vicente, A.; Martín-Closas, C.; Arz, J.A.; Oms, O. Maastrichtian-basal Paleocene charophyte biozonation and its calibration to the Global Polarity Time Scale in the southern Pyrenees (Catalonia, Spain). Cretac. Res. 2015, 52, 268-285. [CrossRef]

61. Vicente, A.; Villalba-Breva, S.; Ferràndez-Cañadell, C.; Martín-Closas, C. Revision of the Maastrichtian-Palaeocene charophyte biostratigraphy of the Fontllonga reference section (Southern Pyrenees, Catalonia, Spain). Geol. Acta 2016, 14, 349-362. [CrossRef]

62. Pereda-Suberbiola, X.; Canudo, J.I.; Cruzado-Caballero, P.; Barco, J.L.; López-Martínez, N.; Oms, O.; Ruiz-Omeñaca, J.I. The last hadrosaurid dinosaurs of Europe: A new lambeosaurine from the Uppermost Cretaceous of Aren (Huesca, Spain). Comptes Rendus Palevol 2009, 8, 559-572. [CrossRef]

63. Fondevilla, V.; Dinarès-Turell, J.; Oms, O. The chronostratigraphic framework of the South-Pyrenean Maastrichtian succession reappraised: Implications for basin development and end-Cretaceous dinosaur faunal turnover. Sediment. Geol. 2016, 337, 55-68. [CrossRef]

64. Puértolas-Pascual, E.; Arenillas, I.; Arz, J.A.; Calvín, P.; Ezquerro, L.; García-Vicente, C.; Pérez-Pueyo, M.; Sánchez-Moreno, E.M.; Villalaín, J.J.; Canudo, J.I. Chronostratigraphy and new vertebrate sites from the upper Maastrichtian of Huesca (Spain), and their relation with the K/Pg boundary. Cretac. Res. 2018, 89, 36-59. [CrossRef]

65. López-Martínez, N.; Vicens, E. A new peculiar dinosaur egg, Sankofa pyrenaica oogen. nov. oosp. nov. from the Upper Cretaceous coastal deposits of the Aren Formation, south-central Pyrenees, Lleida, Catalonia, Spain. Palaeontology 2012, 55, 325-339. [CrossRef]

66. Riera, V. Estudio Integrado (Geología y Paleontología) de la Sucesión de Dinosaurios (Maastrichtiense) de la Vertiente Surpirenaica; Universitat Autónoma de Barcelona: Barcelona, Spain, 2010.

67. López-Martínez, N.; Arribas, M.E.; Robador, A.; Vicens, E.; Ardévol, L. Los carbonatos danienses (Unidad 3) de la Fm Temp (Pirineos sur-centrales): Paleogeografía y relación con el límite Cretácico-Terciario. Rev. Soc. Geol. Esp. 2006, 19, $233-255$.

68. Robador, A.; Samsó, J.M.; Serra-Kiel, J.; Tosquella, J. Field guide. In Introduction to the early Paleogene of the south Pyrenean basin. Field trip Guidebook; Barnolas, A., Robador, A., Serra-Kiel, J., Caus, E., Eds.; IGME: Barcelona, Spain, 1990; pp. $131-159$.

69. Serra-Kiel, P.; Canudo, J.I.; Dinares, J.; Molina, E.; Ortiz, N.; Pascual, J.O.; Samso, J.M.; Tosquella, J. Cronoestratigrafía de los sedimentos marinos del Terciario inferior de la Cuenca de Tremp-Graus (Zona Central Surpirenaica). Rev. Soc. Esp. Geol. 1994, 7, 273-299.

70. Pujalte, V.; Schmitz, B.; Baceta, J.I. Sea-level changes across the Paleocene-Eocene interval in the Spanish Pyrenees, and their possible relationship with North Atlantic magmatism. Palaeogeogr. Palaeoclimatol. Palaeoecol. 2014, 393, 45-60. [CrossRef]

71. Vila, B.; Galobart, Â.; Canudo, J.I.; Le Loeuff, J.; Dinarès-Turell, J.; Riera, V.; Oms, O.; Tortosa, T.; Gaete, R. The diversity of sauropod dinosaurs and their first taxonomic succession from the latest Cretaceous of southwestern Europe: Clues to demise and extinction. Palaeogeogr. Palaeoclimatol. Palaeoecol. 2012, 350-352, 19-38. [CrossRef]

72. López-Martínez, N.; Canudo, J.I.; Ardevol, L.; Pereda-Suberbiola, X.; Orue-Etxebarria, X.; Cuenca-Bescós, G.; Ruiz-Omeñaca, J.I.; Murelaga, X.; Feist, M. New dinosaur sites correlated with upper Maastrichtian pelagic deposits in the Spanish Pyrenees: Implications for the dinosaur extinctio. Cretac. Res. 2001, 22, 41-61. [CrossRef]

73. Garrido Mejías, A.; Ríos Aragües, L.M. Síntesis geológica del Secundario y Terciario entre los ríos Cinca y Segre. Bol. Inst. Geol. Min. Esp. 1972, 83, 1-47. 
74. Canudo, J.I. The Collection of Type Fossils of the Natural Science Museum of the University of Zaragoza (Spain). Geoheritage 2018, 10, 385-392. [CrossRef]

75. Pereda-Suberbiola, X.; Canudo, J.I.; Company, J.; Cruzado-Caballero, P.; Ruiz-Omeñaca, J.I. Hadrosauroid dinosaurs from the latest Cretaceous of the Iberian Peninsula. J. Vertebr. Paleontol. 2009, 29, 946-951. [CrossRef]

76. Cruzado-Caballero, P.; Ruiz-Omeñaca, J.I.; Canudo, J.I. Review of the fossill record of spanish hadrosaur remains. In Proceedings of the VIII Encuentro de Jóvenes Investigadores en Paleontología, Enciso, Spain, 21-22 April 2010; Volume 30, pp. 99-105.

77. Cruzado-Caballero, P.; Puértolas-Pascual, E.; Canudo, J.I.; Castanera, D.; Gasca, J.M.; Moreno-Azanza, M. New hadrosaur remains from the Late Maastrichtian of Huesca (NE Spain). In Proceedings of the 10th Annual Meeting of the European Association of Vertebrate Palaeontologists, Teruel, Spain, 19-24 June 2012; pp. 45-48.

78. Cruzado-Caballero, P.; Ruiz-Omeñaca, J.I.; Gaete, R.; Riera, V.; Oms, O.; Canudo, J.I. A new hadrosaurid dentary from the latest Maastrichtian of the Pyrenees (north Spain) and the high diversity of the duck-billed dinosaurs of the Ibero-Armorican Realm at the very end of the Cretaceous. Hist. Biol. 2014, 26, 619-630. [CrossRef]

79. Company, J.; Cruzado-Caballero, P.; Canudo, J.I. Presence of diminutive hadrosaurids (Dinosauria: Ornithopoda) in the Maastrichtian of the south-central Pyrenees (Spain). J. Iber. Geol. 2015, 41, 71-81. [CrossRef]

80. Prieto-Márquez, A.; Dalla Vecchia, F.M.; Gaete, R.; Galobart, À. Diversity, relationships, and biogeography of the lambeosaurine dinosaurs from the European archipelago, with description of the new aralosaurin Canardia garonnensis. PLoS ONE 2013, 8, e69835. [CrossRef]

81. Conti, S.; Vila, B.; Sellés, A.G.; Galobart, À.; Benton, M.J.; Prieto-Márquez, A. The oldest lambeosaurine dinosaur from Europe: Insights into the arrival of Tsintaosaurini. Cretac. Res. 2020, 107, 104286. [CrossRef]

82. Cruzado-Caballero, P.; Pereda-Suberbiola, X.; Ruiz-Omeñaca, J.I. Blasisaurus canudoi gen. et sp. nov., a new lambeosaurine dinosaur (hadrosauridae) from the latest cretaceous of Arén (Huesca, Spain). Can. J. Earth Sci. 2010, 47, 1507-1517. [CrossRef]

83. Cruzado-Caballero, P.; Canudo, J.I.; Moreno-Azanza, M.; Ruiz-Omeñaca, J.I. New material and phylogenetic position of Arenysaurus ardevoli, a lambeosaurine dinosaur from the late Maastrichtian of Arén (Northern Spain). J. Vertebr. Paleontol. 2013, 33, 1367-1384. [CrossRef]

84. Longrich, N.R.; Suberbiola, X.P.; Pyron, R.A.; Jalil, N.-E. The first duckbill dinosaur (Hadrosauridae: Lambeosaurinae) from Africa and the role of oceanic dispersal in dinosaur biogeography. Cretac. Res. 2020, 104678. [CrossRef]

85. Cruzado-Caballero, P.; Canudo Sanagustín, J.; Ruiz-Omeñaca, J.I. Nuevas evidencias de la presencia de hadrosaurios lambeosaurios (Dinosauria) en el Maastrichtiense superior de la Península Ibérica (Arén, Huesca). Geogaceta 2005, 3, 47-50.

86. Cruzado-Caballero, P.; Canudo, J.I.; Ruiz-Omeñaca, J.I. Los fémures de Blasi (Arén, Huesca, Spain): Una contribución a los hadrosauroideos Europeos del Maastrichtiense superior. In Proceedings of the Actas de las IV Jornadas Internacionales sobre Paleontologia de Dinosaurios y su Entorno, Burgos, Spain, 5-9 September 2009; pp. 197-205.

87. Cruzado-Caballero, P.; Ruiz-Omeñaca, J.I.; Canudo, J.I. Evidencias de la coexistencia de dinosaurios hadrosaurinos y lambeosaurinos en el Maastrichtiano superior de la Península Ibérica (Arén, Huesca, España). Ameghiniana 2010, 47, 153-164. [CrossRef]

88. Canudo, I.; Cruzado-Caballero, P.; Moreno-Azanza, M. Possible theropod predation evidence in hadrosaurid dinosaurs from the Upper Maastrichtian (Upper Cretaceous) of Arén (Huesca, Spain). Kaupia Darmstädter Beiträge zur Naturgeschichte 2005, 14, 9-13.

89. Cruzado-Caballero, P.; Fortuny, J.; Llacer, S.; Canudo, J.I. Paleoneuroanatomy of the European lambeosaurine dinosaur Arenysaurus ardevoli. Peer J. 2015, 2015, 1-16. [CrossRef]

90. Mayayo-Lainez, A. Paleohistología y Mineralogía de los Dinosaurios Hadrosaurios del Maastrichtiense de Arén (Huesca). Master's Thesis, University of Zaragoza, Zaragoza, Spain, 2020.

91. Mayayo-Lainez, A.; Alegre-Esteve, M.; Bauluz, B.; Canudo, J. First approach to the paleohistology of the hadrosaur dinosaurs from Blasi 2A (Tremp Formation, Maastrichtian, Huesca). Ciências Terra-Procedia 2021, 1, 38-41.

92. Puértolas-Pascual, E.; Cruzado-Caballero, P.; Canudo, J.I.; Gasca, J.M.; Moreno-Azanza, M.; Castanera, D.; Parrillas, J.; Ezquerro, L. Nuevos yacimientos de vertebrados del Maastrichtiense superior (Cretácico Superior) de Huesca (España). In Proceedings of the VIII Geological Congress of Spain, Oviedo, Spain, 17-19 July 2012; pp. 269-272.

93. Pérez Pueyo, M.; Puértolas-Pascual, E.; Bádenas, B. Larra 4: Desenterrando a los últimos vertebrados del maastrichtiense terminal del pirineo aragonés. Zubía 2019, 31, 159-163.

94. Pérez-Pueyo, M.; Gilabert, V.; Moreno-Azanza, M.; Puertolas-Pascual, E.; Bádenas, B.; Canudo, J.I. Late Maastrichtian fossil assemblage of Veracruz 1 site (Beranuy, NE Spain): Wildfires and bones in a transitional environment. In Proceedings of the VIII Jornadas Internacionales sobre Paleontología de Dinosaurios y su Entorno, Burgos, Spain, 5-9 September 2019 ; pp. 111-113.

95. Barco, J.L.; Ardevol, L.; Canudo, J.I. Descripción de los primeros rastros asignados a Hadrosauridae (Ornithopoda, Dinosauria) del Maastrichtiense de la Península Ibérica (Areny, Huesca). Geogaceta 2001, 30, 235-238.

96. Vila, B.; Oms, O.; Fondevilla, V.; Gaete, R.; Galobart, À.; Riera, V.; Canudo, J.I. The Latest Succession of Dinosaur Tracksites in Europe: Hadrosaur Ichnology, Track Production and Palaeoenvironments. PLoS ONE 2013, 8, e72579. [CrossRef] [PubMed]

97. Sellés, A.G.; Via, B.; Galobart, À. Spheroolithus europaeus, oosp. nov. (late Maastrichtian, Catalonia), the youngest oological record of hadrosauroids in Eurasia. J. Vertebr. Paleontol. 2014, 34, 725-729. [CrossRef] 
98. Pérez-Pueyo, M.; Moreno-Azanza, M.; Núñez-Lahuerta, C.; Puértolas-Pascual, E.; Bádenas, B.; Canudo, J.I. Eggshell association of the Late Maastrichtian (Late Cretaceous) at Blasi 2B fossil site: A scrambled of vertebrate diversity. Ciências da Terra-Procedia 2021, 1, 58-61.

99. Vila, B.; Sellés, A.G. Re-evaluation of the age of some dinosaur localities from the southern Pyrenees by means of megaloolithid oospecies. J. Iber. Geol. 2015, 41. [CrossRef]

100. Canudo, J.I. Descripcion de un fragmento proximal de fémur de Titanosauridae (Dinosauria, Sauropoda) del Maastrichtiense superior de Serraduy (Huesca). In Proceedings of the XVII Jornadas de la Sociedad Española de Paleontología, Albarracín, Spain, 18-20 October 2001; pp. 255-262.

101. Sellés, A.G.; Marmi, J.; Llácer, S.; Blanco, A. The youngest sauropod evidence in Europe. Hist. Biol. 2016, 28, 930-940. [CrossRef]

102. Fondevilla, V.; Vila, B.; Oms, O.; Galobarp, À. Skin impressions of the last European dinosaurs. Geol. Mag. 2017, 154, 393-398. [CrossRef]

103. Díez Díaz, V.; Pereda Suberbiola, X.; Sanz, J.L. The axial skeleton of the titanosaur Lirainosaurus astibiae (Dinosauria: Sauropoda) from the latest Cretaceous of Spain. Cretac. Res. 2013, 43, 145-160. [CrossRef]

104. Salgado, L.; Coria, R.A.; Calvo, J.O. Evolution of titanosaurid sauropods: Phylogenetic analysis based on the postcranial evidence. Ameghiniana 1997, 34, 3-32.

105. Upchurch, P.; Barrett, P.M.; Dodson, P. 13. Sauropoda. In The Dinosauria, 2nd ed.; University of California Press: Berkeley, CA, USA, 2019; pp. 259-322.

106. Calvo, J.O.; Bonaparte, J.F. Andesaurus delgadoi gen. et. sp. nov. (Saurischia-Sauropoda), dinosaurio Titanosauridae de la Formacion Rio Limay (Albiano-Cenomaniano), Neuquen, Argentina. Ameghiniana 1991, 28, 303-310.

107. Mannion, P.D.; Calvo, J.O. Anatomy of the basal titanosaur (Dinosauria, Sauropoda) Andesaurus delgadoi from the mid-Cretaceous (Albian-early Cenomanian) Río Limay Formation, Neuquén Province, Argentina: Implications for titanosaur systematics. Zool. J. Linn. Soc. 2011, 155-181. [CrossRef]

108. Torices, A.; Currie, P.J.; Canudo, J.I.; Pereda-Suberbiola, X. Theropod dinosaurs from the upper cretaceous of the south pyrenees basin of Spain. Acta Palaeontol. Pol. 2015, 60, 611-626. [CrossRef]

109. Pérez-García, A.; Ortega, F.; Bolet, A.; Escaso, F.; Houssaye, A.; Martínez-Salanova, J.; de Miguel Chaves, C.; Mocho, P.; Narváez, I.; Segura, M.; et al. A review of the upper Campanian vertebrate site of Armuña (Segovia Province, Spain). Cretac. Res. 2016, 57, 591-623. [CrossRef]

110. Pérez-Pueyo, M.; Puértolas-Pascual, E.; Moreno-Azanza, M.; Cruzado-Caballero, P.; Gasca, J.M.; Núñez-Lahuerta, C.; Canudo, J.I. First record of a giant bird (Ornithuromorpha) from the uppermost Maastrichtian of the Southern Pyrenees, NE Spain. J. Vertebr. Paleontol. 2021, 41, e1900210.

111. López-Martínez, N.; Canudo, J.I.; Cuenca-Bescós, G. Latest cretaceous eggshells from Arén (Southern Pyrenees, Spain). In Proceedings of the First International Symposium on Dinosaur Eggs and Babies, Isona, Spain, 23-26 September 1999; pp. 35-36.

112. Núñez-Lahuerta, C.; Moreno-Azanza, M.; Pérez-Pueyo, M. First approach for a taphonomic key for fossil eggs and eggshells accumulations using optic microscopy: The case of Blasi-2B (Upper Cretaceous, Spain). Ciências Terra Procedia 2021, 1, $42-45$.

113. Choi, S.; Moreno-Azanza, M.; Csiki-Sava, Z.; Prondvai, E.; Lee, Y.N. Comparative crystallography suggests maniraptoran theropod affinities for latest Cretaceous European 'geckoid' eggshell. Pap. Palaeontol. 2020, 6, 265-292. [CrossRef]

114. Dalla Vecchia, F.M.; Riera, F.M.; Oms, J.O.; Dinarès-Turell, J.; Gaete, R.; Galobart, A. The last pterosaurs: First record from the uppermost Maastrichtian of the Tremp Syncline (Northern Spain). Acta Geol. Sin. 2013, 87, 1198-1227. [CrossRef]

115. Puértolas, E.; Canudo, J.I.; Cruzado-Caballero, P. A new crocodylian from the late Maastrichtian of Spain: Implications for the initial radiation of crocodyloids. PLoS ONE 2011, 6. [CrossRef]

116. Blanco, A.; Puértolas-Pascual, E.; Marmi, J.; Vila, B.; Sellés, A.G. Allodaposuchus palustris sp. nov. from the Upper Cretaceous of Fumanya (South-Eastern Pyrenees, Iberian Peninsula): Systematics, Palaeoecology and Palaeobiogeography of the Enigmatic Allodaposuchian Crocodylians. PLoS ONE 2014, 9, e115837. [CrossRef]

117. Blanco, A.; Fortuny, J.; Vicente, A.; Luján, À.H.; García-Marçà, J.A.; Sellés, A.G. A new species of Allodaposuchus (Eusuchia, Crocodylia) from the Maastrichtian (Late Cretaceous) of Spain: Phylogenetic and paleobiological implications. Peer J. 2015, 3 , e1171. [CrossRef]

118. Narváez, I.; Brochu, C.A.; Escaso, F.; Pérez-García, A.; Ortega, F. New Crocodyliforms from Southwestern Europe and Definition of a Diverse Clade of European Late Cretaceous Basal Eusuchians. PLoS ONE 2015, 10, e0140679. [CrossRef]

119. Narváez, I.; Brochu, C.A.; Escaso, F.; Pérez-García, A.; Ortega, F. New Spanish Late Cretaceous eusuchian reveals the synchronic and sympatric presence of two allodaposuchids. Cretac. Res. 2016, 65, 112-125. [CrossRef]

120. Mateus, O.; Puértolas-Pascual, E.; Callapez, P.M. A new eusuchian crocodylomorph from the Cenomanian (Late Cretaceous) of Portugal reveals novel implications on the origin of Crocodylia. Zool. J. Linn. Soc. 2019, 186, 501-528. [CrossRef]

121. Puértolas-Pascual, E.; Canudo, J.I.; Moreno-Azanza, M. The eusuchian crocodylomorph Allodaposuchus subjuniperus sp. nov., a new species from the latest Cretaceous (upper Maastrichtian) of Spain. Hist. Biol. 2014, 26, 91-109. [CrossRef]

122. Blanco, A.; Puértolas-Pascual, E.; Marmi, J.; Moncunill-Solé, B.; Llácer, S.; Rössner, G.E. Late Cretaceous (Maastrichtian) crocodyliforms from north-eastern Iberia: A first attempt to explain the crocodyliform diversity based on tooth qualitative traits. Zool. J. Linn. Soc. 2020, 189, 584-617. [CrossRef] 
123. Moreno-Azanza, M.; Bauluz, B.; Canudo, J.I.; Puértolas-Pascual, E.; Sellés, A.G. A re-evaluation of aff. Megaloolithidae eggshell fragments from the uppermost Cretaceous of the Pyrenees and implications for crocodylomorph eggshell structure. Hist. Biol. 2014, 26, 195-205. [CrossRef]

124. Hirsch, K.F. Fossil crocodilian eggs from the eocene of Colorado. J. Paleontol. 1985, 3, 531-542.

125. Vila, B.; Castanera, D.; Marmi, J.; Canudo, J.I.; Galobart, À. Crocodile swim tracks from the latest Cretaceous of Europe. Lethaia 2015, 48, 256-266. [CrossRef]

126. Pérez-Pueyo, M.; Castanera, D.; Bádenas, B.; Canudo, J.I. New evidences of Crocodylomorpha swim tracks in the Maastrichtian of Beranuy (Huesca, Spain). In Proceedings of the XVI Encuentro de Jóvenes Investigadores en Paleontología, Zarautz, Spain, 11-14 April 2018; pp. 137-140.

127. De Lapparent de Broin, F.; Murelaga, X. Turtles from Upper Cretaceous of Lano (Iberian Peninsula). Comptes Rendus l'Académie Sci. 1996, 323, 729-735.

128. Murelaga, X.; Canudo, J.I. Descripción de los restos de quelonios del Maastrichtiense superior de Aren y Serraduy (Huesca). Geogaceta 2005, 28, 51-54.

129. Blain, H.A.; Canudo, J.I.; Cuenca-Bescós, G.; López-Martínez, N. Amphibians and squamate reptiles from the latest Maastrichtian (Upper Cretaceous) of Blasi 2 (Huesca, Spain). Cretac. Res. 2010, 31, 433-446. [CrossRef]

130. Berreteaga, A.; Pereda Suberbiola, X.; Floquet, M.; Olivares, M.; Etxebarria, N.; Iriarte, E.; Badiola Kortabitarte, A.; Elorza, J.; Astibia Ayerra, H. Datos sedimentológicos y tafonómicos de enclaves finicretácicos con fósiles de vertebrados de la Formación Sobrepeña (Burgos, Región Vasco-Cantábrica). Geo-Temas 2008, 10, 1278-1280.

131. Corral, J.-C.; Pueyo, E.L.; Berreteaga, A.; Rodríguez-Pintó, A.; Sánchez, E.; Pereda-Suberbiola, X. Magnetostratigraphy and lithostratigraphy of the Laño vertebrate-site: Implications in the uppermost Cretaceous chronostratigraphy of the BasqueCantabrian Region. Cretac. Res. 2016, 57, 473-489. [CrossRef]

132. Company, J. Vertebrados continentales del Cretácico superior (Campaniense- Maatrichtiense) de Valencia. Ph.D. Thesis, Universidad de Valencia, Valencia, Spain, 2004.

133. Company, J.; Pereda-Suberbiola, X.; Ruiz-Omeñaca, J.I. Last Cretaceous dinosaur faunas from Eastern Iberia into its regional paleogeographic context. Faunal composition and palaeobiogeographical implications. In Proceedings of the IV Jornadas Internacionales sobre Paleontología de Dinosaurios y su Entorno Salas de los Infantes, Burgos, Spain, 5-9 September 2009; pp. $17-44$.

134. Laurent, Y.; Bilotte, M.; Le Loeuff, J. Late Maastrichtian continental vertebrates from southwestern France: Correlation with marine fauna. Palaeogeogr. Palaeoclimatol. Palaeoecol. 2002, 187, 121-135. [CrossRef]

135. Le Loeuff, J.; Buffetaut, E.; Martin, M. The last stages of dinosaur faunal history in Europe: A succession of Maastrichtian dinosaur assemblages from the Corbières (southern France). Geol. Mag. 1994, 131, 625-630. [CrossRef]

136. Prieto-Márquez, A.; Fondevilla, V.; Sellés, A.G.; Wagner, J.R.; Galobart, À. Adynomosaurus arcanus, a new lambeosaurine dinosaur from the Late Cretaceous Ibero-Armorican Island of the European archipelago. Cretac. Res. 2019, 96, 19-37. [CrossRef]

137. Casanovas-Cladellas, M.L.; Santafé-Llopis, J.V.; Isidro-Llorens, A. Pararhabdodon isonensis n. gen. n. sp. (Dinosauria). Estudio mofológico, radio-tomográfico y consideraciones biomecanicas 26-27:121-131. Paleontol. Evol. 1993, 26-27, 121-132.

138. Serrano, J.F.; Sellés, A.G.; Vila, B.; Galobart, À.; Prieto-Márquez, A. The osteohistology of new remains of Pararhabdodon isonensis sheds light into the life history and paleoecology of this enigmatic European lambeosaurine dinosaur. Cretac. Res. 2021, 118, 104677. [CrossRef]

139. Prieto-Marquez, A.; Wagner, J.R. Pararhabdodon isonensis and Tsintaosaurus spinorhinus: A new clade of lambeosaurine hadrosaurids from Eurasia. Cretac. Res. 2009, 30, 1238-1246. [CrossRef]

140. Prieto-Marquez, A.; Gaete, R.; Rivas, G.; Galobart, À.; Boada, M. Hadrosauroid dinosaurs from the Late Cretaceous of Spain: Pararhabdodon isonensis revisited and Koutalisaurus kohlerorum, gen. et sp. nov. J. Vertebr. Paleontol. 2006, 26, 929-943. [CrossRef]

141. Blanco, A.; Prieto-Márquez, A.; De Esteban-Trivigno, S. Diversity of hadrosauroid dinosaurs from the Late Cretaceous IberoArmorican Island (European Archipelago) assessed from dentary morphology. Cretac. Res. 2015, 56, 447-457. [CrossRef]

142. Fondevilla, V.; Dalla Vecchia, F.M.; Gaete, R.; Galobart, À.; Moncunill-Solé, B.; Köhler, M. Ontogeny and taxonomy of the hadrosaur (Dinosauria, Ornithopoda) remains from Basturs Poble bonebed (late early Maastrichtian, Tremp Syncline, Spain). PLoS ONE 2018, 13, e0206287. [CrossRef]

143. Company, J.; Galobart Lorente, À.; Gaete, R. First data on the hadrosaurid dinosaurs (Ornithischia, Dinosauria) from the Upper Cretaceous of Valencia, Spain. Oryctos 1998, 1, 121-126.

144. Pereda-Suberbiola, X.; Pérez-García, A.; Corral, J.C.; Murelaga, X.; Martin, G.; Larrañaga, J.; Bardet, N.; Berreteaga, A.; Company, J. First dinosaur and turtle remains from the latest Cretaceous shallow marine deposits of Albaina (Laño quarry, Iberian Peninsula). Comptes Rendus Palevol. 2015, 14, 471-482. [CrossRef]

145. Santafé, J.V.; Casanovas, M.L.; Llompart, C. Els Dinosaures i el Seu Entorn Geològic; Diputació de Lleida: Lleida, Spain, 1997.

146. López-Martínez, N.; Moratalla, J.J.; Sanz, J.L. Dinosaurs nesting on tidal flats. Palaeogeogr. Palaeoclimatol. Palaeoecol. 2000, 160, 153-163. [CrossRef]

147. Baiano, M.; Galobart, À.; Dalla, F.M.; Vila, B. Aplicación de la microtomografía en el estudio de dientes aislados de dinosaurios terópodos. In Proceedings of the XII Encuentro de Jóvenes investigadores en Paleontología, Boltaña, Spain, 9-12 April 2014; pp. $57-59$. 
148. Marmi, J.; Blanco, A.; Fondevilla, V.; Dalla Vecchia, F.M.; Sellés, A.G.; Vicente, A.; Martín-Closas, C.; Oms, O.; Galobart, À. The Molí del Baró-1 site, a diverse fossil assemblage from the uppermost Maastrichtian of the southern Pyrenees (north-eastern Iberia). Cretac. Res. 2016, 57, 519-539. [CrossRef]

149. Sellés, A.G.; Vila, B.; Brusatte, S.L.; Currie, P.J.; Galobart, À. A fast-growing basal troodontid (Dinosauria: Theropoda) from the latest Cretaceous of Europe. Sci. Rep. 2021, 11, 4855. [CrossRef]

150. Sellés, A.G.; Vila, B.; Galobart, À. Diversity of theropod ootaxa and its implications for the latest cretaceous dinosaur turnover in southwestern Europe. Cretac. Res. 2014, 49, 45-54. [CrossRef]

151. Vianey-Liaud, M.; Lopez-Martinez, N. Late Cretaceous Dinosaur Eggshells from the Tremp Basin, Southern Pyrenees, Lleida, Spain. J. Paleontol. 1997, 71, 1157-1171. [CrossRef]

152. Laurent, Y. Les faunes de vertébrés continentaux du Maastrichtien supérieur d'Europe: Systématique et biodiversité. Strat Série 2003, 41, 1-81.

153. Ogg, J.G.; Hinnov, L.A.; Huang, C. Cretaceous. In The Geologic Time Scale; Elsevier: Amsterdam, The Netherlands, 2012; pp. 793-853.

154. Buffetaut, E.; Clarke, J.B.; Le Loeuff, J. A terminal Cretaceous pterosaur from the Corbieres (southem France) and the problem of pterosaur extinction. Bull. Soc. Geol. Fr. 1996, 167, 753-759.

155. Buffetaut, E.; Laurent, Y.; Le Loeuff, J.; Bilotte, M. A terminal Cretaceous giant pterosaur from the French Pyrenees. Geol. Mag. 1997, 134, 553-556. [CrossRef]

156. Buffetaut, E. Late Cretaceous pterosaurs from France: A review. Zitteliana 2008, 28, $249-255$.

157. Company, J.; Ruiz-Omeñaca, J.I.; Suberbiola, X.P. A long-necked pterosaur (Pterodactyloidea, Azhdarchidae) from the Upper Cretaceous of Valencia, Spain. Geol. Mijnbouw/Netherlands J. Geosci. 1999, 78, 319-333. [CrossRef]

158. Pereda-Suberbiola, X.; Company, J.; Ruiz-Omeñaca, J.I. Azhdarchid pterosaurs from the Late Cretaceous (CampanianMaastrichtian) of the Iberian Peninsula. In Proceedings of the Munich Flugsaurier, The Wellnhofer Pterosaur Meeting, Munich, Germany, 10-14 September 2007; p. 27.

159. Blanco, A.; Méndez, J.M.; Marmi, J. The fossil record of the uppermost Maastrichtian Reptile Sandstone (Tremp Formation, northeastern Iberian Peninsula). Span. J. Paleontol. 2015, 30, 147-160. [CrossRef]

160. Laurent, Y.; Buffetaut, E.; Le Loeuff, J. Un crane de thoracosaurine (Crocodylia, Crocodylidae) dans le Maastrichtien Supérieur du sud de la France. Oryctos 2000, 3, $19-27$.

161. Brochu, C.A. A new Late Cretaceous gavialoid crocodylian from eastern North America and the phylogenetic relationships of thoracosaurs. J. Vertebr. Paleontol. 2004, 24, 610-633. [CrossRef]

162. Le Loeuff, J.; Buffetaut, E.; Cavin, L.; Laurent, Y.; Martin, M.; Martin, V.; Tong, H. Les hadrosaures des Corbières et des Petites Pyrenées. Bull. Soc. Etudes Sci. Aude 1994, 94, 19-21.

163. Buffetaut, E.; Le Loeuff, J. Late Cretaceous dinosaurs from the foothills of the Pyrenees. Geol. Today 1997, 13, 60-68. [CrossRef]

164. Tennant, J.P.; Mannion, P.D.; Upchurch, P. Evolutionary relationships and systematics of Atoposauridae (Crocodylomorpha: Neosuchia): Implications for the rise of Eusuchia. Zool. J. Linn. Soc. 2016, 177, 854-936. [CrossRef]

165. Murelaga, X.; García Garmilla, F.; Pereda Suberbiola, X. Primeros restos de vertebrados del Cretácico Superior de Quecedo de Valdivieso (Burgos). Geogaceta 2005, 195-198.

166. Berreteaga, A. Estudio Estratigráfico, Sedimentológico y Paleontológico de los Yacimientos con Fósiles de Vertebrados del Cretácico Final de la Región Vasco-Cantábrica. Ph.D. Thesis, University of the Basque Country, Bilbao, Spain, 2008.

167. Laurent, Y.; Tong, H.; Claude, J. New side-necked turtle (Pleurodira: Bothremydidae) from the Upper Maastrichtian of the PetitesPyrénées (Haute-Garonne, France). Cretac. Res. 2002, 23, 465-471. [CrossRef]

168. Marmi, J.; Luján, Á.H.; Riera, V.; Gaete, R.; Oms, O.; Galobart, À. The youngest species of Polysternon: A new bothremydid turtle from the uppermost Maastrichtian of the southern Pyrenees. Cretac. Res. 2012, 35, 133-142. [CrossRef]

169. Pérez-García, A. Las tortugas mesozoicas de la Peninsula Ibérica. Ph.D. Thesis, Universidad Complutense de Madrid, Madrid, Spain, 2012.

170. Murelaga, X.; Pereda Suberbiola, X.; Astibia, H.; Lapparent, F.D. Primeros datos sobre los quelonios del Cretácico superior de Lleida. Geogaceta 1998, 24, 239-242.

171. Blanco, A.; Bolet, A.; Blain, H.-A.; Fondevilla, V.; Marmi, J. Late Cretaceous (Maastrichtian) amphibians and squamates from northeastern Iberia. Cretac. Res. 2016, 57, 624-638. [CrossRef]

172. Szentesi, Z.; Company, J. Late Maastrichtian small-sized herpetofauna from Valencia province, eastern Spain. Hist. Biol. 2017, 29, 43-52. [CrossRef]

173. Pol, C.; Buscalioni, A.D.; Carballeira, J.; Francés, V.; López-Martínez, N.; Marandat, B.; Moratalla, J.; Sanz, J.L.; Sigé, B.; Villatte, J. Reptiles and mammals from the Late Cretaceous new locality Quintanilla del Coco (Burgos Province, Spain). Neues Jahrb. Geol. Paläontol. Abh. 1992, 184, 279-314.

174. Gheerbrant, E.; Astibia, H. Addition to the Late Cretaceous Laño mammal faunule (Spain) and to the knowledge of European "Zhelestidae" (Lainodontinae nov.). Bull. Soc. Géol. Fr. 2012, 183, 537-546. [CrossRef]

175. Tabuce, R.; Tortosa, T.; Vianey-Liaud, M.; Garcia, G.; Lebrun, R.; Godefroit, P.; Dutour, Y.; Berton, S.; Valentin, X.; Cheylan, G. New eutherian mammals from the Late Cretaceous of Aix-en-Provence Basin, south-eastern France. Zool. J. Linn. Soc. 2013, 169, 653-672. [CrossRef] 
176. Peláez-Campomanes, P.; López-Martínez, N.; Álvarez-Sierra, M.A.; Daams, R. The earliest mammal of the European Paleocene: The multituberculate Hainina. J. Paleontol. 2000, 74, 701-711. [CrossRef]

177. López-Martínez, N.; Pelaez-Campomanes, P. New mammals from south-central Pyrenees (Tremp Formation, Spain) and their bearing on late Paleocene marine-continental correlations. Bull. Soc. Géol. Fr. 1999, 170, 681-696.

178. Gheerbrant, E.; Abrial, C.; Cappetta, H. Nouveaux sites a microvertébrés continentaux du Crétacé terminal des Petites Pyrénées (Haute-Garonne et Ariège, France). Geobios 1997, 30, 257-269. [CrossRef]

179. Nopcsa, F. Über das Vorkommen der Dinosaurier in Siebenbürgen. Verhandlungen der Zool Gesellschaft 1914, 54, 12-14.

180. Benton, M.J.; Csiki, Z.; Grigorescu, D.; Redelstorff, R.; Sander, P.M.; Stein, K.; Weishampel, D.B. Dinosaurs and the island rule: The dwarfed dinosaurs from Haţeg Island. Palaeogeogr. Palaeoclimatol. Palaeoecol. 2010, 293, 438-454. [CrossRef]

181. Godefroit, P.; Codrea, V.; Weishampel, D.B. Osteology of Zalmoxes shqiperorum (Dinosauria, Ornithopoda), based on new specimens from the Upper Cretaceous of Nălaţ-Vad (Romania). Geodiversitas 2009, 31, 525-553. [CrossRef]

182. Weishampel, D.B.; Jianu, C.; Csiki, Z.; Norman, D.B. Osteology and phylogeny of Zalmoxes (n. g.), an unusual Euornithopod dinosaur from the latest Cretaceous of Romania. J. Syst. Palaeontol. 2003, 1, 65-123. [CrossRef]

183. Weishampel, D.B.; Norman, D.B.; Grigorescu, D. Telmatosaurus transsylvanicus from the late Cretaceous of Romania: The most basal hadrosaurid dinosaur. Palaeontology 1993, 36, 361-385.

184. Dalla Vecchia, F.M. An overview of the latest Cretaceous hadrosauroid record in Europe. In Hadrosaurs; Eberth, D.A., Evans, D.C., Eds.; Indiana University Press: Bloomington, IN, USA, 2014; pp. 268-297.

185. Codrea, V.; Smith, T.; Dica, P.; Folie, A.; Garcia, G.; Godefroit, P.; Van Itterbeeck, J. Dinosaur egg nests, mammals and other vertebrates from a new Maastrichtian site of the Haţeg Basin (Romania). Comptes Rendus Palevol 2002, 1, 173-180. [CrossRef]

186. Vasile, S.; Csiki, Z.; Grigorescu, D. The first report of continental fossil remains from Crăguiş (Haţeg Basin, Romania), and their stratigraphical significance. In Proceedings of the Eighth Romanian Symposium on Paleontology, Bucharest, Romania, 29-30 September 2011; pp. 127-128.

187. Ôsi, A.; Codrea, V.; Prondvai, E.; Csiki-Sava, Z. New ankylosaurian material from the Upper Cretaceous of Transylvania. Ann. Paléontol. 2014, 100, 257-271. [CrossRef]

188. Nopcsa, F. Die dinosaurier der siebenburgischen landesteile ungarns. Mitteilungen aus dem Jahrb. der königlich Ung. Geol. Reichsanstalt 1915, 23, 3-24.

189. Csiki, Z.; Codrea, V.; Jipa-Murzea, C.; Godefroit, P. A partial titanosaur (Sauropoda, Dinosauria) skeleton from the Maastrichtian of Nalat-Vad, Hateg Basin, Romania. Neues Jahrb. Geol. Paläontol. Abhandlungen 2010, 258, 297-324. [CrossRef]

190. Codrea, V.; Vremir, M.; Jipa, C.; Godefroit, P.; Csiki, Z.; Smith, T.; Fărcaş, C. More than just Nopcsa's Transylvanian dinosaurs: A look outside the Haţeg Basin. Palaeogeogr. Palaeoclimatol. Palaeoecol. 2010, 293, 391-405. [CrossRef]

191. Vremir, M.M. New faunal elements from the late Cretaceous (Maastrichtian) continental deposits of Sebeş area (Transylvania). Terra Sebus 2010, 2, 635-684.

192. Csiki, Z.; Vremir, M. A large-sized (?)Late Maastrichtian titanosaur from Rapa Rosie, Sebes. In Proceedings of the 8th Romanian Symposium of Paleontology, Bucharest, Romania, 29-30 September 2011; pp. 28-29.

193. Mannion, P.D.; Díez Díaz, V.; Csiki-Sava, Z.; Upchurch, P.; Cuff, A.R. Dwarfs among giants: Resolving the systematics of the titanosaurian sauropod dinosaurs from the Late Cretaceous of Romania. In Proceedings of the XVII Conference of the EAVP, Brussels, Belgium, 1-6 July 2019; p. 65.

194. Erickson, G.M.; Krick, B.A.; Hamilton, M.; Bourne, G.R.; Norell, M.A.; Lilleodden, E.; Sawyer, W.G. Complex dental structure and wear biomechanics in hadrosaurid dinosaurs. Science 2012, 338, 98-101. [CrossRef]

195. LeBlanc, A.R.H.; Reisz, R.R.; Evans, D.C.; Bailleul, A.M. Ontogeny reveals function and evolution of the hadrosaurid dinosaur dental battery. BMC Evol. Biol. 2016, 16, 152. [CrossRef]

196. Chin, K.; Feldmann, R.M.; Tashman, J.N. Consumption of crustaceans by megaherbivorous dinosaurs: Dietary flexibility and dinosaur life history strategies. Sci. Rep. 2017, 7, 11163. [CrossRef]

197. Vremir, M.; Dyke, G.; Totoianu, R. Repertoire of the late cretaceous vertebrate localities from Sebescedil; area, Alba county (Romania). Terra Sebus 2015, 7, 695-724.

198. Văcărescu, M.R.; Sava, Z.C.; Bucur, M.; Roman, A.; Vasile, S. Theropod dental diversity in the Maastrichtian of the Hațeg Basin, Romania Hateg Basin have yielded a diverse and unique assemblage of vertebrate. In Proceedings of the 11th Romanian Symposium of Paleontology, Bucharest, Romania, 27-28 September 2017; pp. 122-123.

199. Brusatte, S.L.; Vremir, M.; Csiki-Sava, Z.; Turner, A.H.; Watanabe, A.; Erickson, G.M.; Norell, M.A. The Osteology of Balaur bondoc, an Island-Dwelling Dromaeosaurid (Dinosauria: Theropoda) from the Late Cretaceous of Romania. Bull. Am. Museum Nat. Hist. 2013, 374, 1-100. [CrossRef]

200. Csiki, Z.; Vremir, M.; Brusatte, S.L.; Norell, M.A. An aberrant island-dwelling theropod dinosaur from the Late Cretaceous of Romania. Proc. Natl. Acad. Sci. USA 2010, 107, 15357-15361. [CrossRef] [PubMed]

201. Wang, X.; Dyke, G.J.; Codrea, V.; Godefroit, P.; Smith, T. A Euenantiornithine Bird from the Late Cretaceous Ha eg Basin of Romania. Acta Palaeontol. Pol. 2011, 56, 853-857. [CrossRef]

202. Mayr, G.; Codrea, V.; Solomon, A.; Bordeianu, M.; Smith, T. A well-preserved pelvis from the Maastrichtian of Romania suggests that the enigmatic Gargantuavis is neither an ornithurine bird nor an insular endemic. Cretac. Res. 2020, 106, 104271. [CrossRef] 
203. Sallam, H.M.; Gorscak, E.; O'Connor, P.M.; El-Dawoudi, I.A.; El-Sayed, S.; Saber, S.; Kora, M.A.; Sertich, J.J.W.; Seiffert, E.R.; Lamanna, M.C. New Egyptian sauropod reveals Late Cretaceous dinosaur dispersal between Europe and Africa. Nat. Ecol. Evol. 2018, 2, 445-451. [CrossRef] [PubMed]

204. Tortosa, T.; Buffetaut, E.; Vialle, N.; Dutour, Y.; Turini, E.; Cheylan, G. A new abelisaurid dinosaur from the Late Cretaceous of southern France: Palaeobiogeographical implications. Ann. Paléontol. 2014, 100, 63-86. [CrossRef]

205. Buffetaut, E.; Grigorescu, D.; Csiki, Z. A new giant pterosaur with a robust skull from the latest Cretaceous of Romania. Naturwissenschaften 2002, 89, 180-184. [CrossRef] [PubMed]

206. Naish, D.; Witton, M.P. Neck biomechanics indicate that giant Transylvanian azhdarchid pterosaurs were short-necked arch predators. Peer J. 2017, 5, e2908. [CrossRef]

207. Solomon, A.A.; Codrea, V.A.; Venczel, M.; Grellet-Tinner, G. A new species of large-sized pterosaur from the Maastrichtian of Transylvania (Romania). Cretac. Res. 2020, 110, 104316. [CrossRef]

208. Rabi, M.; Delfino, M. A reassessment of the "alligatoroid" eusuchian from the Late Cretaceous of Hungary and its taxonomic implications. In Proceedings of the 10th Annual Meeting of the European Association of Vertebrate Palaeontologists, Teruel, Spain, 19-24 June 2012; pp. 203-206.

209. Martin, J.E.; Rabi, M.; Csiki, Z. Survival of Theriosuchus (Mesoeucrocodylia: Atoposauridae) in a Late Cretaceous archipelago: A new species from the Maastrichtian of Romania. Naturwissenschaften 2010, 97, 845-854. [CrossRef]

210. Martin, J.E.; Rabi, M.; Csiki-Sava, Z.; Vasile, Ş. Cranial morphology of Theriosuchus sympiestodon (Mesoeucrocodylia, Atoposauridae) and the widespread occurrence of Theriosuchus in the Late Cretaceous of Europe. J. Paleontol. 2014, 88, 444-456. [CrossRef]

211. Rabi, M.; Sebők, N. A revised Eurogondwana model: Late Cretaceous notosuchian crocodyliforms and other vertebrate taxa suggest the retention of episodic faunal links between Europe and Gondwana during most of the Cretaceous. Gondwana Res. 2015, 28, 1197-1211. [CrossRef]

212. Sellés, A.G.; Blanco, A.; Vila, B.; Marmi, J.; López-Soriano, F.J.; Llácer, S.; Frigola, J.; Canals, M.; Galobart, À. A small Cretaceous crocodyliform in a dinosaur nesting ground and the origin of sebecids. Sci. Rep. 2020, 10, 15293. [CrossRef]

213. Rabi, M.; Vremir, M.; Tong, H. Preliminary Overview of Late Cretaceous Turtle Diversity in Eastern Central Europe (Austria, Hungary, and Romania). In Morphology and Evolution of Turtles. Vertebrate Paleobiology and Paleoanthropology; Brinkman, D., Holroyd, P., Gardner, J., Eds.; Springer: Dordrecht, The Netherlands, 2013; pp. 307-336.

214. Pérez-García, A.; Codrea, V. New insights on the anatomy and systematics of Kallokibotion Nopcsa, 1923, the enigmatic uppermost Cretaceous basal turtle (stem Testudines) from Transylvania. Zool. J. Linn. Soc. 2018, 182, 419-443. [CrossRef]

215. Venczel, M.; Gardner, J.D.; Codrea, V.A.; Csiki-Sava, Z.; Vasile, S..; Solomon, A.A. New insights into Europe's most diverse Late Cretaceous anuran assemblage from the Maastrichtian of western Romania. Palaeobiodivers. Palaeoenviron. 2016, 96, 61-95. [CrossRef]

216. Grigorescu, D.; Venczel, M.; Csiki, Z.; Limberea, R. New microvertebrate fossil assemblages from the Uppermost Cretaceous of the Hațeg Basin (Romania). Geol. Mijnb. 1999, 78, 301-314. [CrossRef]

217. Folie, A.; Codrea, V. New lissamphibians and squamates from the Maastrichtian of Haţeg Basin, Romania. Acta Palaeontol. Pol. 2005, 50, 57-71.

218. Codrea, V.A.; Venczel, M.; Solomon, A. A new family of teiioid lizards from the Upper Cretaceous of Romania with notes on the evolutionary history of early teiioids. Zool. J. Linn. Soc. 2017. [CrossRef]

219. Vasile, Ş.; Csiki-Sava, Z.; Venczel, M. A new madtsoiid snake from the Upper Cretaceous of the Haţeg Basin, western Romania. J. Vertebr. Paleontol. 2013, 33, 1100-1119. [CrossRef]

220. Venczel, M.; Vasile, Ş.; Csiki-Sava, Z. A Late Cretaceous madtsoiid snake from Romania associated with a megaloolithid egg nest-Paleoecological inferences. Cretac. Res. 2015, 55, 152-163. [CrossRef]

221. Pereda-Suberbiola, X.; Corral, J.C.; Astibia, H.; Badiola, A.; Bardet, N.; Berreteaga, A.; Buffetaut, E.; Buscalioni, A.D.; Cappetta, H.; Cavin, L.; et al. Late Cretaceous continental and marine vertebrate assemblages from the Laño quarry (Basque-Cantabrian Region, Iberian Peninsula): An update. J. Iber. Geol. 2015, 41. [CrossRef]

222. Csiki, Z.; Grigorescu, D.; Rücklin, M. A new multituberculate specimen from the Maastrichtian of Pui, Romania and a reassessment of affinities of Barbatodon. Acta Palaeontol. Rom. 2005, 5, 73-86.

223. Smith, T.; Codrea, V. Red iron-pigmented tooth enamel in a multituberculate mammal from the Late Cretaceous Transylvanian "Haţeg Island". PLoS ONE 2015, 10, e0132550. [CrossRef]

224. Csiki-Sava, Z.; Vremir, M.; Meng, J.; Brusatte, S.L.; Norell, M.A. Dome-headed, small-brained island mammal from the Late Cretaceous of Romania. Proc. Natl. Acad. Sci. USA 2018, 115, 4857-4862. [CrossRef]

225. De Bast, E.; Smith, T. The oldest Cenozoic mammal fauna of Europe: Implication of the Hainin reference fauna for mammalian evolution and dispersals during the Paleocene. J. Syst. Palaeontol. 2017, 15, 741-785. [CrossRef]

226. Brocklehurst, N.; Kammerer, C.F.; Fröbisch, J. The early evolution of synapsids, and the influence of sampling on their fossil record. Paleobiology 2013, 39, 470-490. [CrossRef]

227. Purnell, M.A.; Donoghue, P.C.J. Between death and data: Biases in interpretation of the fossil record of conodonts-The Palaeontological Association. Spec. Pap. Palaeontol. 2005, 25, 7-25.

228. Benton, M.J.; Dunhill, A.M.; Lloyd, G.T.; Marx, F.G. Assessing the quality of the fossil record: Insights from vertebrates. Geol. Soc. Lond. Spec. Publ. 2011, 358, 63-94. [CrossRef] 
229. Benton, M.J.; Pearson, P.N. Speciation in the fossil record. Trends Ecol. Evol. 2001, 16, 405-411. [CrossRef]

230. Grigorescu, D.; Csiki-Sava, Z.; Vasile, Ş.; Butiseacă, G.-A. Taphonomic biases in macro- and microvertebrate assemblages from the Maastrichtian of the Hateg Basin (Romania) and their relevance in the reconstruction of a fossil ecosystem. In Proceedings of the 9th Annual Meeting of the European Association of Vertebrate Palaeontologists, Heraklion, Greece, 14-19 June 2011; pp. $28-29$.

231. Chiarenza, A.A.; Mannion, P.D.; Lunt, D.J.; Farnsworth, A.; Jones, L.A.; Kelland, S.-J.; Allison, P.A. Ecological niche modelling does not support climatically-driven dinosaur diversity decline before the Cretaceous/Paleogene mass extinction. Nat. Commun. 2019, 10, 1091. [CrossRef]

232. Teixell, A.; Labaume, P.; Lagabrielle, Y. The crustal evolution of the west-central Pyrenees revisited: Inferences from a new kinematic scenario. Comptes Rendus Geosci. 2016, 348, 257-267. [CrossRef]

233. Fondevilla, V.; Vila, B.; Galobart, À.; Oms, O. Taphonomic modes in the dinosaur-bearing Tremp Formation (Maastrichtian, Southern Pyrenees). In Proceedings of the XIV Annual Meeting of the European Association of Vertebrate Palaeontologists, Haarlem, The Netherlands, 6-10 July 2016; p. 223.

234. Upchurch, P.; Mannion, P.D.; Benson, R.B.J.; Butler, R.J.; Carrano, M.T. Geological and anthropogenic controls on the sampling of the terrestrial fossil record: A case study from the Dinosauria. Geol. Soc. Lond. Spec. Publ. 2011, 358, 209-240. [CrossRef]

235. Le Loeuff, J. Paleobiogeography and biodiversity of Late Maastrichtian dinosaurs: How many dinosaur species went extinct at the Cretaceous-Tertiary boundary? Bull. Soc. Géol. Fr. 2012, 183, 547-559. [CrossRef] 